\title{
Vicarius Christi: Extraterritoriality, pastoral power, and the critique of secular international law
}

\author{
Daniel Ricardo Quiroga-Villamarín*(1) \\ Graduate Institute of International and Development Studies, Chemin Eugène-Rigot 2A, 1202 Genève, Switzerland \\ Email: daniel.quiroga@graduateinstitute.ch
}

\begin{abstract}
Since the end of the Cold War, the content, scope, and extent of extraterritorial human rights obligations has become a pressing concern for international lawyers. On one end of the debate, mainstream scholarship argues that jurisdiction is primarily territorial, identifying a limited range of situations in which jurisdiction (and responsibility) is triggered. On the other end, critical scholars suggest that Empire still haunts jurisdiction. By reconstructing the history of this doctrine, they show that the imperial reach has always been extra-territorial and that the intimate linkage between state, territory, and population is of a rather recent and tenuous origin. In both of these narratives, however, lies the assumption that jurisdiction operates as a secularized power. Even if empires/states were once religious, faith's legacy remains confined to the past. In this article, conversely, I trace a critical genealogy of Christian authority as a jurisdictional structure, in which territoriality was never presumed. After all, one cannot forget that Catholicism and Universalism were forged in the same etymological crucible. By drawing from Foucault's analysis of pastoral power, I argue that international law has deep roots in Christianity's claims of governmentality upon 'men and souls' instead of over defined territories.
\end{abstract}

Keywords: Catholicism; extraterritoriality; history and theory of international law; jurisdiction; Secularism

In Exodus, it is said to Yahweh: 'In your faithful love you led out the people you had redeemed; in your strength you have guided them to your holy pastures.' So, in contrast with the power exercised on the unity of a territory, pastoral power is exercised on a multiplicity on the move. ${ }^{1}$

The most 'secular' of our political concepts - sovereignty and property - have found their sharpest articulations within a theological debate about justifying the authority human beings claim over each other. ${ }^{2}$

${ }^{\star}$ I thank Matthew Craven, Juan Amaya-Castro, Janne Nijman, and the anonymous reviewers and editors for their generous comments on this piece. The usual caveat applies.

${ }^{1}$ M. Foucault, Security, Territory, Population: Lectures at the College de France, 1977 - 78 (2007), 126.

${ }^{2}$ M. Koskenniemi, 'International Law and Religion: No Stable Ground', in M. Koskenniemi, M. García-Salmones and P. Amorosa (eds.) International Law and Religion: Historical and Contemporary Perspectives (2017), 1, at 14.

(c) The Author(s), 2021. Published by Cambridge University Press. This is an Open Access article, distributed under the terms of the Creative Commons Attribution licence (http://creativecommons.org/licenses/by/4.0/), which permits unrestricted re-use, distribution, and reproduction in any medium, provided the original work is properly cited. 


\section{Introduction}

It is no secret that the early 1990s were a period of high expectations and hopes in the power of international law. ${ }^{3}$ In the 'post-Cold War' moment, the dream of a 'so-called' rule-based international order that had been shackled by the bipolar stalemate was set free, under the wings of American hegemony. ${ }^{4}$ While this 'new world order ${ }^{5}$ is increasingly under siege nowadays, ${ }^{6}$ it created lasting anxieties for the discipline. One salient issue has been the extraterritorial human rights obligations of states under international law. ${ }^{7}$ While the exercise of powers (both executive or judicial) beyond the frontiers of the nation-state long predated the 1990s, this new age of 'muscular humanitarianism' ${ }^{8}$ and American unipolarity ${ }^{9}$ created new challenges for the application or lack thereof - of 'humanity's law' in the interstices of Empire. ${ }^{10}$ These challenges, of course, only grew when the age of global optimism collapsed in $2001,{ }^{11}$ giving rise to a time of legal black holes, endless exceptions, and the global war on terror. ${ }^{12}$ This historical conjecture brought the question of limits and borders (both disciplinary and geographical) to the forefront. ${ }^{13}$

Thus, in the last two decades, mainstream international law scholarship (MILS) ${ }^{14}$ has set out to address these challenges from a doctrinal perspective. In this vein, ${ }^{15}$ MILS has identified the rare situations in which international law may have an extra-ordinary reach. From state responsibility to the laws of war, from business and human rights to economic and social rights, each sub-regime of public international law has a series of (contested) rules and principles for extraterritorial application (Section 2.1). On the other end of the discipline, a diverse chorus of voices from critical, third world, and new(er) stream perspectives have highlighted that the MILS's narratives fail to fully account for the role of Empire in the extraterritorial (and, for that matter, territorial) application of international law. ${ }^{16}$ Absent from these two strands of literature, however, are any

${ }^{3}$ J. von-Bernstorff, 'The Decay of the International Rule of Law Project (1990-2015)', in H. Krieger, G. Nolte and A. Zimmermann (eds.) The International Rule of Law: Rise or Decline? (2019), 33. In contrast see M. Craven, S. Pahuja and G. Simpson (eds.), International Law and the Cold War (2020).

${ }^{4}$ M. Reisman, 'International Law after the Cold War', (1990) 84 AJIL 859; J. Alvarez, 'Hegemonic International Law Revisited', (2003) 97 AJIL 873.

${ }^{5}$ A. Slaughter, A New World Order (2005).

${ }^{6}$ A. Pert, 'International Law in a Post-Post-Cold War World-Can It Survive?: Current Challenges to International Law', (2017) 4 Asia \& the Pacific Policy Studies 362; D. Quiroga-Villamarín, 'From Speaking Truth to Power to Speaking Power's Truth: Transnational Judicial Activism in an Increasingly Illiberal World', in B. Baade et al. (eds.), Cynical International Law? Abuse and Circumvention in Public International and European Law (2020), 111.

${ }^{7}$ For an overview see R. Ridderhof and P. Ulmer, 'Extraterritoriality: Selective Bibliography', Hague Academy of International Law, 2019, available at www.peacepalacelibrary.nl/wp-content/uploads/2019/08/Update-3-Centre-2019Extraterritoriality-SelectiveBibliography-General.pdf.

${ }^{8}$ A. Orford, 'Muscular Humanitarianism: Reading the Narratives of the New Interventionism', (1999) 10 EJIL 679.

${ }^{9}$ M. Byers and G. Nolte (eds.), United States Hegemony and the Foundations of International Law (2003).

${ }^{10} \mathrm{R}$. Teitel, Humanity's Law (2011); A. Orford, Reading Humanitarian Intervention: Human Rights and the Use of Force in International Law (2003); S. Chesterman, Just War or Just Peace?: Humanitarian Intervention and International Law (2002).

${ }^{11} \mathrm{H}$. Koh, 'The Law under Stress after September 11', (2003) 31 International Journal of Legal Information 317.

${ }^{12}$ N. Bhuta, 'A Global State of Exception? The United States and World Order', (2003) 10 Constellations 371.

${ }^{13}$ A. Orford, 'A Jurisprudence of the Limit', in A. Orford (ed.), International Law and Its Others (2006), 1; Y. Blank and I. Rosen-Zvi, 'Introduction: The Spatial Turn in Social Theory', (2010) 10 Hagar 1.

${ }^{14}$ On MILS as a category see B. Chimni, International Law and World Order: A Critique of Contemporary Approaches (2017), 12 et seq. See also A. Bianchi, International Law Theories (2016), 21-43.

${ }^{15}$ P. Schlag, 'Law as the Continuation of God by Other Means', (1997) 85 California Law Review 427; J. d'Aspremont, International Law as a Belief System (2017).

${ }^{16}$ Inter alia, A. Anghie and B. Chimni, 'Third World Approaches to International Law and Individual Responsibility in Internal Conflicts', (2003) 2 Chinese Journal of International Law 77; A. Anghie and W. McCormack, 'The Rights of Aliens: Legal Regimes and Historical Perspectives', in K. Korinek and T. Maloney (eds.), Migration in the 21st Century: Rights, Outcomes, and Policy (2011), 23; M. Tait Slys, Exporting Legality: The Rise and Fall of Extraterritorial Jurisdiction in the Ottoman Empire and China (2014); B. Chimni, 'Capitalism and Jurisdiction Over Time: The Case of Extraterritorial Jurisdiction', available at graduateinstitute.ch/sites/default/files/2019-02/Program_Spring\%202019_ International\%20Law\%20Colloquium.pdf; D. Margolies et al. (eds.), The Extraterritoriality of Law: History, Theory, 
considerations on the religious origins of extraterritorial jurisdiction. While scholars of both strands are willing to concede that religion once played an important role in the past of jurisdictional practices, they do not follow the implications and consequences of this trajectory for our present (and future) discussions on extraterritoriality. For these two narratives, the state (and even the Empire, in the Third World Approaches to International Law [TWAIL] tradition) appears as a secularized cold monster. ${ }^{17}$ But, as our contemporary resurgence of religion shows, ${ }^{18}$ perhaps our dreams of 'modern secularism' were not much more than wishful thinking. ${ }^{19}$ Indeed, it seems to be more accurate to say that religion never went away.

Hence, in this article, I set out to complement the critical perspective by highlighting the importance of the Christian pastoral in our contemporary imagination of the exercise of power over mobile flocks rather than geographical borders. ${ }^{20}$ If critical international lawyers are to understand the elusive mystery of contemporary global governance, ${ }^{21}$ we ought to not only engage with the history of the state or of capitalism but also with the history of Christianity. ${ }^{22}$ To do so, in what follows I will briefly review (Section 2) the narratives of extraterritoriality in international law, in both the MILS (Section 2.1) and new(er) Stream (Section 2.2) traditions. I will conclude that both (Section 2.3) reproduce a secularized understanding of jurisdiction in international law. To dispel this presumption, I will draw and contribute from (Section 3) the literature on postsecularism in, and beyond, international law. The diverse contributions of this field might enable us to rethink our assumptions about the secularized jurisdiction of international law. ${ }^{23}$ With this in mind, I then proceed to (Section 4) trace a genealogy of jurisdiction as a technology of Christian authority, in which the office of the pastor has played a salient role. I conclude by arguing that (Section 5) the pastoral model of office still haunts our understanding of the discipline, especially when it comes to the imagination of boundless jurisdiction.

As Koskenniemi notes, 'religion' and 'international law' are themselves polysemic and disputed notions, which leaves ample ground for ambiguity and contestation when one attempts to engage between them. Importantly, he notes that both religion and international law could be seen as ideological systems, a set of norms or cultural practices, or an account of authoritative institutions. ${ }^{24}$ I am particularly interested in understanding religion as a series of practices and technologies that we might call 'jurisdictional' rather than as a system of beliefs and rites a la Durkheim. ${ }^{25}$ In fact, following Pahuja and Eslava or Benton, I am also interested in thinking of international law as a set of material and bureaucratic activities that occur in the everyday interactions between rival jurisdictions, and not only as an ideological and philosophical project of world-making. ${ }^{26}$ If, as Cover argued, jurisdiction is nothing more (but also nothing less) than a particular narrative in which law grounds its ability to speak authoritatively on behalf of itself, ${ }^{27}$ I conclude that both

Politics (2019). See also the forthcoming monograph M. Pal, Jurisdictional Accumulation: An Early Modern History of Law, Empires and Capital (2020).

${ }^{17}$ F. Nietzsche, Thus Spoke Zarathustra: A Book for All and None (2006), 34.

${ }^{18}$ G. Lambert, Return Statements: The Return of Religion in Contemporary Philosophy (2016); M. Graziano, Holy Wars and Holy Alliance: The Return of Religion to the Global Political Stage (2017).

${ }^{19}$ C. Taylor, A Secular Age (2018).

${ }^{20}$ B. Golder, 'Foucault and the Genealogy of Pastoral Power', (2007) 10 Radical Philosophy Review 157.

${ }^{21}$ D. Kennedy, 'The Mystery of Global Governance', (2008) 43 Ohio Northern University Law Review 827.

${ }^{22}$ J. Haskell, 'Political Theology and International Law', (2018) 1(2) Brill Research Perspectives in International Legal Theory and Practice 1.

${ }^{23}$ S. Dorsett and S. McVeigh, Jurisdiction (2012).

${ }^{24}$ See Koskenniemi, supra note 2, at 17-18.

${ }^{25}$ E. Durkheim, The Elementary Forms of Religious Life (2008), 46.

${ }^{26}$ L. Eslava and S. Pahuja, 'Between Resistance and Reform: TWAIL and the Universality of International Law', (2011) 3 Trade, Law and Development 103, 125-6; L. Benton, 'Beyond Anachronism: Histories of International Law and Global Legal Politics', (2019) 21 Journal of the History of International Law 7.

${ }^{27}$ R. Cover, 'The Folktales of Justice: Tales of Jurisdiction', in M. Minow, M. Ryan and A. Sarat (eds.), Narrative, Violence, and the Law: The Essays of Robert Cover (1992), 173. 
MILS and critical perspectives stand much to gain from a greater engagement with the pastoral technologies embedded in jurisdictional technologies of normative worldmaking. As Cover knew well, rituals and spiritual exercises have long been elements of the juris-generative spectacle required to make the law speak. ${ }^{28}$

\section{Narratives of Extraterritoriality in International Law}

\subsection{MILS - 'primarily' + 'territorial'}

Recent scholarship has shed light on the importance of framing in the creation of authoritative narratives - legal or otherwise. ${ }^{29}$ When it comes to MILS on extraterritoriality, these approaches often follow a common narrative: 'a series of rehearsed moves: defining extraterritoriality, identifying key cases and statutory backgrounds, and compartmentalizing its application into discrete legal contexts' ${ }^{30}$ Thus, in this genre, authors often start by defining jurisdiction as primarily territorial, framing extraterritorial jurisdiction as the exception. ${ }^{31}$ Along these lines, the leading monographs are structured as both justifications and implementation guides of narrowly defined cases of extraterritorial application of human rights discourse. ${ }^{32}$

Then, they proceed to analyse the few cases in which this unsurmountable contradiction might be resolved, by clarifying the limited grounds of which the exception becomes the rule. After all, they must face the Vienna Convention on the Law of Treaties (VCLT)'s clause that states that, unless a different intention is stated, a treaty must be understood to have territorial implications. ${ }^{33}$ This usually leads to the jurisdictional clauses of human rights instruments, and the well-worn paths of the difference between jurisdiction and territory. ${ }^{34}$ In his pioneer piece, for instance, Meron suggests that the International Covenant on Civil and Political Right (ICCPR)'s mention of jurisdiction or territory paved the road for the extraterritorial application of human rights norms in Haiti. ${ }^{35}$ Ever since, it has become commonplace to echo Meron's preoccupation for a restrictive territorial application without seriously challenging the 'territorial presumption'. ${ }^{36}$

\footnotetext{
${ }^{28}$ R. Cover, 'Foreword: Nomos and Narrative', (1983) 97 Harvard Law Review 4; R. Cover, 'Violence and the Word', (1986) 95 Yale Law Journal 1601.

${ }^{29}$ Inter alia, M. Wählisch, 'Cognitive Frames of Interpretation in International Law', in A. Bianchi, D. Peat and M. Windsor (eds.), Interpretation in International Law (2015), 331; M. Windsor, 'Narrative Kill or Capture: Unreliable Narration in International Law', (2015) 28 LJIL 743; R. Urueña, 'International Law as Expert Knowledge', in J. d'Aspremont et al. (eds.), International Law as a Profession (2017), 389.

${ }^{30}$ J. Haskell, 'Ways of Doing Extraterritoriality in Scholarship', in Margolies et al., supra note 16, at 14.

${ }^{31}$ A. Clapham, 'VI Jurisdiction', in A. Clapham (ed.), Brierly's Law of Nations: An Introduction to the Role of International Law in International Relations (2012), 206; C. Ryngaert, Jurisdiction in International Law (2015), 101; C. Stalker, 'Jurisdiction', in M. D. Evans (ed.), International Law (2018), 289, at 293.

${ }^{32}$ See, for instance, some of the leading monographs: S. Skogly, Beyond National Borders: States' Human Rights Obligations in International Cooperation (2006); M. Gondek, The Reach of Human Rights in a Globalising World: Extraterritorial Application of Human Rights Treaties (2009); M. Gibney and S. Skogly, Universal Human Rights and Extraterritorial Obligations (2010); M. Milanovic, Extraterritorial Application of Human Rights Treaties: Law, Principles, and Policy (2011): K. da Costa, The Extraterritorial Application of Selected Human Rights Treaties (2012). Most of these volumes focus on civil and political rights. In contrast see M. Langford et al. (eds.), Global Justice, State Duties: The Extraterritorial Scope of Economic, Social, and Cultural Rights in International Law (2013).

${ }^{33} 1969$ VCLT, 1155 UNTS 331, Art. 21.

${ }^{34} 1966$ ICCPR, 999 UNTS 177, Art. 2(1); 1950 European Convention for the Protection of Human Rights and Fundamental Freedoms, as amended by Protocols 11 and 14, ETS 5, Art. 1; 1969 American Convention on Human Rights, 1144 UNTS 123 , Art. 1.

${ }^{35}$ T. Meron, 'Extraterritoriality of Human Rights Treaties', (1995) 89 AJIL 78.

${ }^{36} \mathrm{~V}$. Mantouvalou, 'Extending Judicial Control in International Law: Human Rights Treaties and Extraterritoriality', (2005) 9 International Journal of Human Rights 147; R. Wilde, 'Triggering State Obligations Extraterritorially: The Spatial Test in Certain Human Rights Treaties', (2007) 40 Israel Law Review 503; H. King, 'The Extraterritorial Human Rights Obligations of States', (2009) 9 Human Rights Law Review 521; S. Miller, 'Revisiting Extraterritorial Jurisdiction: A Territorial Justification for Extraterritorial Jurisdiction under the European Convention', (2009) 20 EJIL
} 
Immediately after, MILS contribution often proceeds to clarify which are those cases of territoryless jurisdiction. Hathaway and others, just to cite a leading example, note the 'remarkable degree of coherence and consistency' of the 'effective control test', ${ }^{37}$ as almost all international and domestic courts have almost every time upheld this standard. ${ }^{38}$ Although this test was initially created by the International Court of Justice (ICJ) in its Nicaragua 1986 case to address questions of state responsibility, it has come to dominate the conversation on extraterritorial application of human rights law. ${ }^{39}$ For this reason, MILS contributions spend a considerable amount of time clarifying the relationships between international human rights law (IHRL) and the regime of state responsibility, even if these two regimes feed into each other. ${ }^{40}$

Although the initial judgments of the European Court of Human Rights (ECtHR) seemed to open the possibility for a wide margin of application for human rights extraterritorial obligations, ${ }^{41}$ the controversial Bancović decision in 2001 effectively entrenched the effective control as the appropriate standard. ${ }^{42}$ In this case, which dealt with the alleged human rights violations caused by NATO's aerial campaign during the Yugoslav wars, the court initially shunned the possibility of applying the European Convention on Human Rights (ECHR) beyond the espace juridique of its contracting parties. ${ }^{43}$ To do this, the Court - just like the MILS interventions - started by stressing that a state jurisdictional competence is 'primarily territorial'. ${ }^{44}$ Grounding its analysis on Article 31.3.c of the VCLT and the principle that the ECHR cannot be interpreted in a vacuum due to the need for systemic integration, ${ }^{45}$ the Court argued that extraterritoriality can only be accepted in 'exceptional cases' ${ }^{46}$ They reinforce this interpretation by delving also into the travaux préparatoires of the ECHR, which - considering the colonial fervour of its drafters - seems to prove the point. ${ }^{47}$ While the plaintiffs in Bancović might seem naïve to contemporary spectators, it would be important to forget that this application was filed in a time of high hopes in the potential uses of international law to bring accountability for human rights violations. It attempted to be the equivalent of the Tadic judgment for IHRL. ${ }^{48}$ While we now know that Serbia's attempt to bring NATO to justice was systematically denied before the International Criminal Tribunal

1223; G. Goodwin-Gill, 'The Extra-Territorial Reach Of Human Rights Obligations: A Brief Perspective on The Link To Jurisdiction', in M. Kohen and L. Boisson-De-Chazournes (eds.), International Law and the Quest for Its Implementation (2010), 289; B. Miltner, 'Revisiting Extraterritoriality after Al-Skeini: The ECHR and Its Lessons', (2012) 33 Michigan Journal of International Law 693; V. Tzevelekos, 'Reconstructing the Effective Control Criterion in Extraterritorial Human Rights Breaches: Direct Attribution of Wrongfulness, Due Diligence, and Concurrent Responsibility', (2014) 36 Michigan Journal of International Law 129.

${ }^{37}$ O. Hathaway et al., 'Human Rights Abroad: When Do Human Rights Treaty Obligations Apply Extraterritorially?', (2011) 43 Arizona State Law Journal 389.

${ }^{38}$ To paraphrase L. Henkin, How Nations Behave: Law and Foreign Policy (1979), 47.

${ }^{39}$ Military and Paramilitary Activities in and Against Nicaragua (Nicaragua v. United States of America), Merits, Judgment of 27 June 1986, [1986] ICJ Rep. 14, at 35-70, paras. 75-125.

${ }^{40} \mathrm{M}$. Gibney, K. Tomasevski and J. Vedsted-Hansen, 'Transnational State Responsibility for Violations of Human Rights', (1999) 12 Harvard Human Rights Journal 267; O. De Schutter, 'State Responsibility and “Jurisdiction”, in O. De Schutter (ed.), International Human Rights Law: Cases, Materials, Commentary (2010), 123.

${ }^{41}$ Soering v. United Kingdom, Judgment of 7 July 1989, [1989] ECHR (Ser. A), para. 88; Loizidou v. Turkey, Decision of 23 March 1995, [1995] ECHR (Ser. A), para. 56.

${ }^{42}$ Banković et al. v. Belgium et al., Decision of 12 December 2001, [2001] ECHR XII.

${ }^{43}$ Ibid., para. 80. See also, K. Altiparmak, 'Bankovic: An Obstacle to the Application of the European Convention on Human Rights in Iraq?', (2004) 9 Journal of Conflict and Security Law 213; A. Bianchi, 'Choice and (the Awareness of) Its Consequences: The ICJ's "Structural Bias" Strikes Again in the Marshall Islands Case', (2017) 111 AJIL Unbound 81-7, at 86 , fn 30 .

${ }^{44}$ Banković, supra note 42 , para. 59.

${ }^{45}$ Ibid., para. 57. See further, P. Merkouris, Article 31(3)(c) VCLT and the Principle of Systemic Integration: Normative Shadows in Plato's Cave (2015).

${ }^{46}$ Banković, supra note 42 , para. 67.

${ }^{47}$ See Art. 56(1) of the ECHR. See further, M. Duranti, The Conservative Human Rights Revolution: European Identity, Transnational Politics, and the Origins of the European Convention (2017).

${ }^{48}$ Prosecutor v. Dusko Tadic, Judgement, Case No. IT-94-1-A, A. Ch., 15 July 1999, paras. 68-171. 
for the Former Yugoslavia (ICTY), the ICJ, and now the ECtHR. ${ }^{49}$ At this exact same time, international lawyers celebrated the establishment of the International Criminal Court and the triumph of the movement against impunity. ${ }^{50}$

What matters, at any rate, is that Bancovic set the trend that would be later rehearsed and repeated by both MILS and the later judgments of international courts and tribunals: only extraordinary cases of effective control by a state could trigger the application of IHRL obligations (and, mutatis mutandis, the law of state responsibility). ${ }^{51}$ It required 'boots on the ground', so to say, to engage international law. ${ }^{52}$ This was later ratified (in a perhaps clearer manner) by the nowleading decisions of Al Skeini and Al-Jedda. ${ }^{53}$ Whether it is effective control or the exercise of public powers, only in very limited circumstances might imperial power fall under the guise of the ECHR. ${ }^{54}$ As Vandenhole concluded, ' $\mathrm{t}$ ] he ECtHR has drifted somewhat between a spatial, personal, and checkpoint model, each of which tends to inhibit rather than to further extraterritorial jurisdiction beyond the exceptional'. ${ }^{5}$

This trend was also reinforced by the ICJ in its advisory opinion on The Construction of a Wall (2004), its judgment on Democratic Republic of the Congo v. Uganda (2005), or even in the recent decision on the preliminary objections filed by Russia in its case against Ukraine. ${ }^{56}$ A similar story might be told regarding litigation of law of nations claims under the Alien Tort Claims Act (ATCA) before American courts after the Supreme Court (re)enshrined a controversial presumption against extraterritoriality in Kiobel. ${ }^{57}$ Unsurprisingly, the Inter-American Court of Human Rights has also adopted the effective control test, recently restating its relevance in its advisory opinion on the relationship between the environment and human rights. ${ }^{58}$ In sum, MILS frames the issue of extraterritorial obligations as the exception, which are only triggered in cases of effective control (i.e, 'boots on the ground'). Some of these scholarly interventions compare the nuances between particular courts, jurisdictions, or regimes of international law. ${ }^{59}$ Others critically

\footnotetext{
${ }^{49}$ Among others, Legality of Use of Force (Yugoslavia v. United Kingdom), Provisional Measures, Order of 2 June 1999 , [1999] ICJ Rep. 826; C. Del Ponte, Madame Prosecutor: Confrontations with Humanity's Worst Criminals and the Culture of Impunity: A Memoir (2009).

${ }^{50} \mathrm{G}$. Simpson, Law, War and Crime: War Crimes Trials and the Reinvention of International Law (2007).

${ }^{51}$ Despite Cassese's dissent. See A. Cassese, 'The Nicaragua and Tadic Tests Revisited in Light of the ICJ Judgment on Genocide in Bosnia', (2007) 18 EJIL 649.

${ }^{52}$ K. Trapp, 'Boots (on the Ground)', in J. Hohmann and D. Joyce (eds.), International Law's Objects (2018), 151 , at 154.

${ }^{53}$ Al-Skeini and ors, Bar Human Rights Committee (intervening) and ors (intervening) v. United Kingdom, Judgment of 7 July 2011, [2011] ECHR; Al-Jedda, Liberty (intervening) and JUSTICE (intervening) v. United Kingdom, Judgment of 7 July 2011, [2011] ECHR.

${ }^{54}$ M. Zgonec-Rožej, 'Al-Skeini v. United Kingdom', (2012) 106 AJIL 131; M. Milanovic, 'Al-Skeini and Al-Jedda in Strasbourg', (2012) 23 EJIL 121.

${ }^{55} \mathrm{~W}$. Vandenhole, 'The “J” Word: Driver or Spoiler of Change in Human Rights Law?', in S. Allen et al. (eds.), The Oxford Handbook of Jurisdiction in International Law (2019), 412, at 429.

${ }^{56} \mathrm{R}$. Wilde, 'Human Rights Beyond Borders at the World Court: The Significance of the International Court of Justice's Jurisprudence on the Extraterritorial Application of International Human Rights Law Treaties', (2013) 12 Chinese Journal of International Law 639. See also Legal Consequences of the Construction of a Wall in the Occupied Palestinian Territory, Advisory Opinion of 9 July 2004, [2004] ICJ Rep. 136; Armed Activities on the Territory of the Congo (Congo, the Democratic Republic of the v. Uganda), Merits, Judgment of 19 December 2005, ICJ Rep. 168; Application of the International Convention for the Suppression of the Financing of Terrorism and of the International Convention on the Elimination of All Forms of Racial Discrimination (Ukraine v. Russian Federation), Preliminary Examination, Judgment of 8 November 2019, [2019] ICJ Rep. 558.

${ }^{57}$ Kiobel v. Royal Dutch Petroleum Co., 569 U.S. 108 (Sup. Ct. 2013). See further R. Alford, 'Human Rights After Kiobel: Choice of Law and the Rise of Transnational Tort Litigation', (2014) 63 Emory Law Journal 1089; A. Grear and B. Weston, 'The Betrayal of Human Rights and the Urgency of Universal Corporate Accountability: Reflections on a Post-Kiobel Lawscape', (2015) 15 Human Rights Law Review 21.

${ }^{58}$ Advisory Opinion on the Environment and Human Rights, OC-23/2017, 15 November 2017, paras. 79-82.

${ }^{59}$ S. Ben-Natan, 'Constitutional Mindset: The Interrelations between Constitutional Law and International Law in the Extraterritorial Application of Human Rights', (2017) 50(2) Israel Law Review 139-76.
} 
interrogate the pitfalls of 'human rights imperialism' ${ }^{60}$ None of these works, however, truly challenges the presumption on territoriality.

\subsection{New(er) streams: The visible hand of empire}

On the other end of the discipline, voices along the 'critical and socio-legal spectrum' ${ }^{61}$ rise in arms against the assumption of territoriality. These emerging trends of scholarship led the editors of the recently published Oxford Handbook of Jurisdiction in International Law to conclude that 'extraterritoriality is increasingly viewed as a starting point for the exercise for state jurisdiction, rather than as an exception'. ${ }^{62}$ In their view, historical studies and theoretical interventions -especially of those whom they regard to be affiliated with the critical legal studies (CLS) movement have complicated the 'fairly ritualized account' usually offered by MILS. ${ }^{63}$ For these reasons, along with the doctrinal analysis, they have included special sections related to history and theory in their handbook. ${ }^{64}$ In what follows, I will briefly review these rising cohorts of 'socio-critical' perspectives. Some of these authors are closely affiliated with the TWAIL movement. ${ }^{65}$ Others are rather closer to the law and society movement and arrived at the issue of jurisdiction through the debates on legal pluralism. ${ }^{66}$ Many of them were closely related to the New Approaches to International Law (NAIL) movement in the $\mathrm{US}^{67}$ or the Critical Legal Conference in the UK. ${ }^{68}$ Others are closer to the revival of Marxism, within and beyond international law. ${ }^{69}$ In sum, I will attempt to group together a wide tent of approaches that one could call critical, that attempt to engage with postcolonial, feminist, post-structural, and post-Marxist thought to understand and deconstruct international law's presumption of territoriality. ${ }^{70}$

Perhaps their manifesto can be found in the (also recently published) edited volume The Extraterritoriality of Law. ${ }^{71}$ By historicizing, politicizing, and theorizing jurisdiction, they show that the notion of 'extra-territoriality' seems to presume the natural and objective authority and legitimacy of state-centric territorial governance. ${ }^{72}$ In contrast, they attempt to contextualize

\footnotetext{
${ }^{60} \mathrm{R}$. Wilde, 'Compliance With Human Rights Norms Extraterritorially: "Human Rights Imperialism”?', in Kohen and Boisson-de-Chazournes, supra note 36, at 315; N. Bhuta (ed.), The Frontiers of Human Rights: Extraterritoriality and Its Challenges (2016).

${ }^{61}$ M. Davies, Law Unlimited: Materialism, Pluralism, and Legal Theory (2017), 14.

${ }^{62}$ S. Allen et al., 'Introduction: Defining State Jurisdiction and Jurisdiction in International Law', in Allen et al., supra note 55,2 , at 8 .

${ }^{63}$ Ibid., at 7, 12.

${ }^{64}$ Ibid., Part II - 'History' (Ch. 2-5) and Part III - 'Theory' (Ch. 6-9). Contrast with Part IV ‘General International Law' or Part V 'Contextualizing Jurisdiction - Substantive and Institutional Issue'.

${ }^{65} \mathrm{See}$, as an overview, A. Anghie and B. S. Chimni, 'Third World Approaches to International Law and Individual Responsibility in Internal Conflicts', (2003) 2 Chinese Journal of International Law 77; B. S. Chimni, 'Third World Approaches to International Law: A Manifesto', (2006) 8 International Community Law Review 3; Eslava and Pahuja, supra note 26; G. Abi-Saab, 'The Third World Intellectual in Praxis: Confrontation, Participation, or Operation Behind Enemy Lines?', (2016) 37 Third World Quarterly 1957, at 1958; Bianchi, supra note 14, at 205-26.

${ }^{66}$ P. Berman, Global Legal Pluralism: A Jurisprudence of Law beyond Borders (2012).

${ }^{67}$ D. Kennedy, 'When Renewal Repeats: Thinking against the Box', in W. Brown and J. Halley (eds.), Left Legalism/Left Critique (2002), 373; A. Rasulov, 'New Approaches to International Law: Images of a Genealogy', in J. M. Beneyto and D. Kennedy (eds.), New Approaches to International Law: The European and the American Experiences (2013), 151; I. rua Wall, 'The Mytho-Poetics of Critical Legal (Secret) Society', Critical Legal Thinking, 2 May 2019, available at criticallegalthinking.com/2019/05/02/the-mytho-poetics-of-critical-legal-secret-society/.

${ }^{68}$ C. Douzinas, 'The Responsibilities of the Critic: Law, Politics, and the Critical Legal Conference', in E. Christodoulidis, R. Dukes and M. Goldoni (eds.), Research Handbook on Critical Legal Theory (2019), 223.

${ }^{69}$ S. Marks (ed.), International Law on the Left: Re-Examining Marxist Legacies (2008); A. Rasulov, 'A Marxism for International Law: A New Agenda', (2018) 29 EJIL 631. Further, see the 'Legal Form' blog, legalform.blog/about/.

${ }^{70}$ On the ambiguities of 'critical' international law see A. Rasulov, 'What Is Critique?: Towards a Sociology of Disciplinary Heterodoxy in Contemporary International Law', in d'Aspremont et al., supra note 29, at 189.

${ }^{71}$ See Margolies et al., supra note 16.

${ }^{72}$ D. Margolies et al., 'Introduction', in ibid., 1, at 1.
} 
debates about extraterritoriality in the processes of 'state-building, imperialist rivalry, and capitalist expansion' in which they emerged, hoping to better understand their past legacies, present perils, and unstable futures. ${ }^{73}$ Drawing from a wide array of insights from historians, ${ }^{74}$ sociologists, ${ }^{75}$ geographers, ${ }^{76}$ and critical international relations scholars, ${ }^{77}$ they show that the marriage between authority and territory is one of recent (and rather tenuous) origin, forged in the crucible of empire.

The first part of the volume is composed of theoretical contributions. In this vein, Haskell maps different narratives, highlighting that TWAIL perspectives turn 'away from a Cartesian grid-like conception of the world to a new environment defined by collapsing time and space, with the human subject caught in dense, technologically enhanced webs of information' ${ }^{78}$ This echoes Valverde's invitation to understand jurisdictional practices as techniques of spatial and temporal governance. ${ }^{79}$ In her chapter, Seck argues that we should take this critique a step further, to engage the critique of extraterritoriality with the 'seductive' (but dangerous) concept of the Anthropocene. ${ }^{80}$ While this notion might be elusive (at its best) and politically problematic (at its worst), it does give us grounds to de-centre the 'human subject'. ${ }^{81}$ Finally, Sziegeti concludes this part by arguing that it may be futile to distinguish the 'extra' from the 'territorial'. ${ }^{82}$ As he aptly shows, while MILS often narrated the pre-Second World War epoch as the 'era of strict territoriality', they conveniently forget to mention that these were also the times of large colonial empires and extraterritorial courts. ${ }^{83}$ The primacy of the 'territorial' only hides the long hand of Empire.

Sziegeti's chapter serves nicely as a transition for the second part of the book, which encompasses a series of case studies related to the historical emergence of extraterritoriality. Drawing from previous historical analyses, ${ }^{84}$ these chapters conclude that extraterritoriality emerged in the context of uneven development, imperial expansion, and capital accumulation. ${ }^{85}$ In fact, they show that the 'dynamic of difference' and the discourse of civilization led to the division of the

\footnotetext{
${ }^{73}$ Ibid., at 2.

${ }^{74}$ L. Benton, Law and Colonial Cultures: Legal Regimes in World History, 1400-1900 (2001); L. Benton, A Search for Sovereignty: Law and Geography in European Empires, 1400-1900 (2009). See further P. Singh, 'Lauren Benton and Lisa Ford. Rage for Order: The British Empire and the Origins of International Law, 1800-1850 Andrew Fitzmaurice. Sovereignty, Property and Empire, 1500-2000', (2017) 28 EJIL 975; T. Herzog, Frontiers of Possession: Spain and Portugal in Europe and the Americas (2015).

${ }^{75}$ S. Sassen, Territory, Authority, Rights: From Medieval to Global Assemblages (2008).

${ }^{76}$ S. Elden, The Birth of Territory (2013); S. Elden, 'Legal Terrain—the Political Materiality of Territory', (2017) 5 London Review of International Law 199.

${ }^{77} \mathrm{~B}$. Teschke, The Myth of 1648: Class, Geopolitics, and the Making of Modern International Relations (2003).

${ }^{78}$ See Haskell, supra note 30 , at 23.

${ }^{79}$ M. Valverde, Chronotopes of Law: Jurisdiction, Scale, and Governance, Social Justice (2015); M. Valverde, 'Deepening the Conversation between Socio-Legal Theory and Legal Scholarship about Jurisdiction', in Allen et al., supra note 55, at 160.

${ }^{80} \mathrm{~S}$. Seck, 'Moving beyond the E-Word in the Anthropocene', in Margolies et al., supra note 16, 49, at 56.

${ }^{81}$ A. Grear, 'Deconstructing Anthropos: A Critical Legal Reflection on "Anthropocentric" Law and Anthropocene "Humanity", (2015) 26 Law and Critique 225.

${ }^{82} \mathrm{P}$. Szigeti, 'In the Middle of Nowhere: The Futile Quest to Distinguish Territoriality from Extraterritoriality', in Margolies et al., supra note 16 , at 30 .

${ }^{83}$ Ibid., at 37.

${ }^{84}$ T. Ruskola, 'Colonialism without Colonies: On the Extraterritorial Jurisprudence of the U.S. Court for China', (2008) 71 Law and Contemporary Problems 217; T. Kayaoglu, Legal Imperialism: Sovereignty and Extraterritoriality in Japan, the Ottoman Empire, and China (2010); Anghie and McCormack supra note 16; Tait Slys, supra note 16; U. Özsu, 'The Ottoman Empire, the Origins of Extraterritoriality, and International Legal Theory', in A. Orford and F. Hoffmann (eds.). The Oxford Handbook of the Theory of International Law (2016), 123.

${ }^{85} \mathrm{~K}$. Miles, “Uneven Empires”: Extraterritoriality and the Early Trading Companies', in Margolies et al., supra note 16, 87, at 100 .
} 
globe into fuzzy world-systems of civilized, semi-civilized, and barbaric peoples. ${ }^{86}$ Even if at the core the procedures and techniques of governance were slowly linked to 'territory', ${ }^{87}$ at the margins in fact what occurred was a brutal encounter between rival jurisdictional that competed until there were no longer 'white spaces on a map'. ${ }^{88}$ Thus, those peoples that were deemed barbaric were swallowed by imperial polities, while semi-civilized peoples attempted to walk the tightrope of state-building under the white man's burden. ${ }^{89}$ We must, however, resist seeing this as a linear process of 'universalization' of the state-form and the jus publicum Europaeum..$^{90}$ Instead, the new(er) stream convincingly argues that private companies, imperial bureaucrats, mestizo and creole local elites, and bandits - both stationary and roving - played their role in the assembling of the unstable polities we have come to imagine as nation-states. ${ }^{91}$ In this vein, Tuori reminds us that the only historically accurate use of the adjective 'Westphalian' is related to dogs, not world orders. $^{92}$

Along these lines, Pal offers a historical materialist account of the rise of Early Modern systems of diplomacy in Europe. ${ }^{93}$ Rather than stressing religious strife, she posits that class (and the emergence of the burgher class in particular) explains the diverging patterns of diplomatic immunities that emerged in England and the Netherlands vis-à-vis France and Spain, challenging the mainstream narrative offered by Eurocentric histories of diplomacy. ${ }^{94}$ Horowitz's analysis of extraterritoriality in Qing China, ${ }^{95}$ Taha's reconstruction of the jurisprudence of the mixed courts of Egypt, ${ }^{96}$ and Tzouvala's trace of extraterritoriality in Siam ${ }^{97}$ show how semi-civilized peoples struggled to claim their sovereignty in contexts of imperial pressure. These interventions should

\footnotetext{
${ }^{86}$ A. Anghie, Imperialism, Sovereignty and the Making of International Law (2005); L. Obregón, 'Peripheral Histories of International Law', (2019) 15 Annual Review of Law and Social Science 437.

${ }^{87}$ R. Ford, 'Law's Territory (A History of Jurisdiction)', (1999) 97 Michigan Law Review 843; M. Foucault, Society Must Be Defended: Lectures at the College de France, 1975-76 (2003); Foucault, supra note 1; Elden, supra note 76 (2013, 2017).

${ }^{88} \mathrm{~L}$. Benton, 'Colonial Law and Cultural Difference: Jurisdictional Politics and the Formation of the Colonial State', (1999) 41 Comparative Studies in Society and History 563; V. Nesiah, 'Placing International Law: White Spaces on a Map', (2003) 16 LJIL 1; S. Pahuja, 'Laws of Encounter: A Jurisdictional Account of International Law', (2013) 1 London Review of International Law 63; N. M. Rajkovic, 'The Visual Conquest of International Law: Brute Boundaries, the Map, and the Legacy of Cartogenesis', (2018) 31 LJIL 267.

${ }^{89} \mathrm{M}$. Craven, 'Between Law and History: The Berlin Conference of $18840 \hat{u} 1885$ and the Logic of Free Trade', (2015) 3 London Review of International Law 31.

${ }^{90}$ S. Pahuja, Decolonising International Law: Development, Economic Growth and the Politics of Universality (2011), 5-6; T. Herzog, Short History of European Law: The Last Two and a Half Millennia (2019).

${ }^{91} J$. Barreto, 'Cerberus: Rethinking Grotius and the Westphalian System', in M. Koskenniemi, W. Rech and M. Jiménez (eds.), International Law and Empire: Historical Explorations (2017); L. Benton and L. Ford, Rage for Order: The British Empire and the Origins of International Law, 1800-1850 (2016); L. Obregón, 'Completing Civilization: Creole Consciousness and International Law in Nineteenth-Century Latin America', in Orford, supra note 13, at 247; A. Lorca, Mestizo International Law: A Global Intellectual History 1842-1933 (2014); M. Olson, 'Dictatorship, Democracy, and Development', (1993) 87 The American Political Science Review 567; M. Billig, Banal Nationalism (1995); B. Anderson, Imagined Communities: Reflections on the Origin and Spread of Nationalism (2006).

${ }^{92} \mathrm{~K}$. Tuori, 'The Beginnings of State Jurisdiction in International Law until 1648', in Allen et al., supra note 55, at 27, fn 6.

${ }^{93} \mathrm{M}$. Pal, 'Early Modern Extraterritoriality, Diplomacy, and the Transition to Capitalism', in Margolies et al., supra note 16, at 69 .

${ }^{94}$ See also C. Tilly, Coercion, Capital, and European States, AD 990-1992 (1992).

${ }^{95} \mathrm{R}$. Horowtiz, 'Protégé Problems: Qing Officials, Extraterritoriality, and Global Integration in Nineteenth-Century', in Margolies et al., supra note 16, at 104.

${ }^{96}$ M. Taha, 'Drinking Water by the Sea: Real and Unreal Property in the Mixed Courts of Egypt', in ibid., at 119.

${ }^{97} \mathrm{~N}$. Tzouvala, “'And the Laws Are Rude, ... Crude and Uncertain": Extraterritoriality and the Emergence of Territorialised Statehood in Siam', in ibid., at 134.
} 
be read in tandem with Özsu, Ruskola, Kayaoglu, and Tait Slys' work on the Ottoman Empire, China, and Japan ${ }^{98}$ and Parffit's work on Ethiopia ${ }^{99}$ to reach a harrowing conclusion: statehood is always conditioned. For the peoples of the South, territorial statehood is always precarious and unstable, constrained to the fulfilment of imperial standards of race; civilization; development; alien/human rights. ${ }^{100}$ Thus, extraterritorial jurisdiction is nothing less than Empire's visible hand, extending far beyond the 'territorial' limits of the centre. In the longue durée of the many jurisdictional assemblages mobilized to exert imperial control, the illusion of territoriality is little more than a recent and precarious assumption.

\subsection{When renewal repeats: Secular international law}

Critical scholars, as we have seen, have raised important challenges to MILS's presumption of territoriality. In fact, by problematizing territory, these new voices have highlighted the persistence of the specter of Empire in our contemporary understandings of jurisdiction in international law (and IHRL in particular). They show, to paraphrase Anghie, the 'haunting ancestral connections' between the Age of Empires and our supposedly postcolonial epoch. ${ }^{101}$ Sadly, sometimes attempts at disciplinary renewal might end in repetitions of the canon. ${ }^{102}$ It seems that both critical perspectives and MILS tend to repeat a common gesture when it comes to the analysis of jurisdiction (extraterritorial or not): the presumption of secularism. While critical and mainstream international lawyers are quick to concede that religion (and Christianity in particular) played an important role in the creation of the classical Droit des Gens, they are also keen to argue that now international law has now been effectively secularized. ${ }^{103}$ Religion, as Kennedy noted back in 1999 , is 'something we used to have'. ${ }^{104}$

In fact, for many, international law 'as such' was born from the critique of religion of the Spanish Scholastic tradition. ${ }^{105}$ Unsurprisingly, many link its rise to the work of its 'founding fathers': the protestant secularizers of the Early Modern period. For Tuori and George, Grotius founded international law when he famously took God out of the equation. ${ }^{106}$ For others, Vattel, ${ }^{107}$ or Kant, ${ }^{108}$ inter alia, are to be credited for the gesture of secularization. One cannot fail to see that these histories reproduce a mythology that nineteenth-century international lawyers struggled hard to entrench: the story of international law is a system of positive law, clearly

\footnotetext{
${ }^{98}$ See supra note 82.

${ }^{99}$ R. Parfitt, The Process of International Legal Reproduction: Inequality, Historiography, Resistance (2019).

${ }^{100}$ N. Wheatley, 'Spectral Legal Personality in Interwar International Law: On New Ways of Not Being a State', (2017) 35 Law and History Review 753.

${ }^{101}$ A. Anghie, 'Politic, Cautious, and Meticulous: An Introduction to the Symposium on the Marshall Islands Case', (2017) 111 AJIL Unbound 62, at 62.

${ }^{102}$ See Kennedy, supra note 67.

${ }^{103}$ See further R. Paz, 'Religion, Secularism, and International Law', in Orford and Hoffmann, supra note 84, at 923; E. Decaux, 'Les Influences Réciproques Entre Religion(s) et Droit International', in R. Uerpmann-Wittzack, E. Lagrange and S. Oeter (eds.), Religion and International Law: Living Together (2018), 353.

${ }^{104} \mathrm{D}$. Kennedy, 'Images of Religion in International Legal Theory', in M. Janis and C. Evans (eds.), Religion and International Law (1999), 145, at 145.

${ }^{105}$ See Tuori, supra note 92, at 38; Paz, supra note 103, at 924-5; M. Koskenniemi, 'Empire and International Law: The Real Spanish Contribution', (2011) 61 University of Toronto Law Journal 1, at 7. See also M. Keys, 'Religion, Empire, and Law among Nations in The City of God: From the Salamanca School to Augustine, and Back Again', in Koskenniemi, GarcíaSalmones and Amorosa, supra note 2, at 64.

${ }^{106}$ Tuori, ibid., at 38; W. George, 'Grotius, Theology, and International Law: Overcoming Textbook Bias', (1999) 14 Journal of Law and Religion 605, at 609-11; M. Koskenniemi, 'Imagining the Rule of Law: Rereading the Grotian Tradition' (2019) 30 EJIL 17, at 23.

${ }^{107}$ S. Beaulac, 'The Lotus Case in Context: Sovereignty, Westphalia, Vattel, and Positivism', in Allen et al., supra note 55, at 40 .

${ }^{108}$ S. Wittich, 'Immanuel Kant and Jurisdiction in International Law', in ibid., at 81.
} 
separated from religions or moral considerations. ${ }^{109}$ As Janis noted back in 1989, the 'fever to the form' that accompanied the development of international law as a scientific project has been very effective displacing religion from the agenda. ${ }^{110}$ At the time of writing, contemporary scholarship tends to address narrow questions of religious freedom and vivre ensemble. ${ }^{111}$ Interestingly enough, when religion is seldomly addressed, it is in the context of Europe's others. ${ }^{112}$ See, for instance, Yahaya's work on Islamic and Hindu jurisdictional thought, ${ }^{113}$ or the recent volume International Law and Islam. ${ }^{114}$ By drawing from and contributing to the recent or forthcoming works on Catholicism and International law, ${ }^{115}$ I argue that international lawyers can and should engage productively with the history of this religion to better understand the past, present, and history of international authority. As we will see, one of Christianity's salient distinctions from the previous canon of legal and political thinking in the Western tradition is that it embraced a boundless jurisdictional outlook. While other political models were territorialized around the polis or limited to specific groups, Christianity, since its inception, claimed an evangelical scope to govern over 'men and souls' with no consideration of boundaries. After all, one cannot forget that Catholicism and Universalism were forged in the same etymological crucible. ${ }^{116}$ I argue that contemporary international lawyers - however secularized - continue to act within this tradition of pastoral imagination, in which authority spills beyond any territorial containment: in the name of humanity.

\section{The critique of the secular in - and beyond - international law}

In his introductory chapter to the trail-blazing volume International Law and Religion, Koskenniemi noted that there was 'no stable ground' for this line of critique, as international law's 'self-confident secularism' had left the question of religion as an 'almost uncharted territory'. ${ }^{117}$ Against the grain, this volume holds together a series of contributions that chart the inheritances, discontinuities, and tensions of religious thought for contemporary international law. A pioneer

\footnotetext{
${ }^{109}$ M. García-Salmones, The Project of Positivism in International Law (2013). See also M. Koskenniemi, The Gentle Civilizer of Nations: The Rise and Fall of International Law 1870-1960 (2001).

${ }^{110}$ M. Janis et al., 'Religion and International Law', (1988) 82 Proceedings of the Annual Meeting 195.

${ }^{111} \mathrm{~J}$. Witte and M. C. Green (eds.), Religion and Human Rights: An Introduction (2011); M. D. Evans, P. Petkoff and J. Rivers (eds.), The Changing Nature of Religious Rights under International Law (2015); R. Uerpmann-Wittzack, E. Lagrange and S. Oeter (eds.), Religion and International Law: Living Together (2018); N. Bhuta (ed.), Freedom of Religion, Secularism, and Human Rights (2019).

${ }^{112}$ J. Haskell, 'Subjectivity and Structures: The Challenges of Methodology in the Study of the History of International Law and Religion', in I. de la Rasilla and A. Shahid (eds.), International Law and Islam: Historical Explorations (2018), 90.

${ }^{113}$ N. Yahaya, 'The European Concept of Jurisdiction in the Colonies', in Allen et al., supra note 55, at 64-5. See also M. Ramadan, 'Muslim Jurists' Criteria for the Division of the World into Dar al-Harb and Dar al-Islam', in Koskenniemi, GarcíaSalmones and Amorosa, supra note 2, at 219.

${ }^{114}$ I. de la Rasilla and A. Shahid (eds.), International Law and Islam: Historical Explorations (2018).

${ }^{115} \mathrm{P}$. Amorosa, Rewriting the History of the Law of Nations: How James Brown Scott Made Francisco de Vitoria the Founder of International Law (2019); L. F. Taylor, Catholic Cosmopolitanism and Human Rights (2020); J. Haskell and P. Slotte (eds.), Christianity and International Law (forthcoming in 2021); S. Shortall and D. Steinmetz-Jenkins (eds.), Christianity and Human Rights Reconsidered (2020); D. M. Lantigua, Infidels and Empires in a New World Order: Early Modern Spanish Contributions to International Legal Thought (2020).

${ }^{116} \mathrm{D}$. Ricardo Quiroga-Villamarín, “'An Atmosphere of Genuine Solidarity and Brotherhood”: Hernán Santa-Cruz and a Forgotten Latin American Contribution to Social Rights', (2019) 21 Journal of the History of International Law 71, at 83. See also N. Berman, “'The Sacred Conspiracy”: Religion, Nationalism, and the Crisis of Internationalism’, (2012) 25 LJIL 9.

${ }^{117}$ See Koskenniemi, supra note 2 , at 4-6.
} 
intervention along these lines was offered by Moyn in his historical reconstruction of the Christian origins of core human rights doctrines. ${ }^{118}$ In this vein, Nijman complicates Grotius' claims to 'paternity' of international law, by showing how his allegedly secularizing move could be better understood as one particular way of protestant theology in the context of the Calvinist-Arminian dispute. ${ }^{119}$ Haivry traces the international maritime law back to its Jewish theological foundations. ${ }^{120}$ In turn, Porras highlights the importance of the Christian notion of 'providence' for our contemporary faith in free trade, while Tallgren explores the relevance of faith for the project of international criminal law. ${ }^{121}$

In this article, I want not only to draw from works in international law, but also from a broader literature post-secular literature in the humanities. For both better or worse, the literature has been indebted to Schmitt's Political Theology (and, for international law, his Nomos of the Earth). These works have been seminal references for the critique of liberal secularism, at both the national and global scales. ${ }^{122}$ These insights were found to be particularly productive for critical theorists at the dawn of the post-Cold War period, as they gave us important tools to dissect the coming age of endless war and liberal and secular imperialism. ${ }^{123}$ For example, Agamben draws from Schmitt and the critique of theology in his multi-tome Homo Sacer intellectual project. ${ }^{124}$ By analysing the intersections between Roman legal institutions, Catholic rites of liturgy, and capitalist practices of accumulation, Agamben sets out to trace a history of sovereign power in the Western tradition. ${ }^{125}$ His genealogy of duty and office will be of particular relevance for my argument in Section $4 .{ }^{126}$

From another angle, Asad suggested the time was nigh for an 'anthropology of the secular' ${ }^{127}$ In his book, Asad sought to decentre the traditional narrative of secularism that begins with the devastating European religious wars of the sixteenth century to the triumphant rise of the secular modern territorial state, questioning its blind spots and shortcomings. His 'history of the present $^{\prime 28}$ (openly preoccupied by the so-called 'resurgence of religion' since September 2001) traced a genealogy of the emergence of the 'secular' in the framework of 'modernity'. ${ }^{129}$ His book not only sheds light on the troubled and contested emergence of secularism in western discourse but also explores the consequences of its imperial expansion along the Middle East. To do so, he recognizes that secular is 'neither singular in origin nor stable in its historical identity, although it works through a series of particular oppositions', ${ }^{130}$ such as 'belief and knowledge, reason and imagination, history and fiction, natural and supernatural, sacred and profane'. ${ }^{131}$

${ }^{118}$ S. Moyn, Christian Human Rights (2015), 67. See also A. Brett, 'Human Rights and the Thomist Tradition', in P. Slotte and M. Halme-Tuomisaari (eds.), Revisiting the Origins of Human Rights (2015), 82; P. Slotte, “Blessed Are the Peacemakers": Christian Internationalism, Ecumenical Voices, and the Quest for Human Rights', in Slotte and Halme-Tuomisaari, ibid., at 293; Duranti, supra note 47.

${ }^{119}$ J. Nijman, 'Grotius' Imago Dei Anthropology: Grounding Ius Naturae et Gentium', in Koskenniemi, García-Salmones and Amorosa, supra note 2, at 87.

${ }^{120}$ O. Haivry, 'John Selden and the Jewish Religious Fountainhead of the International Law of the Sea', in ibid., at 111.

${ }^{121}$ I. Porras, 'The Doctrine of the Providential Function of Commerce in International Law: Idealizing Trade', in ibid., at 313; I. Tallgren, 'The Faith in Humanity and International Criminal Law', in ibid., at 334.

${ }^{122}$ C. Schmitt, Political Theology: Four Chapters on the Concept of Sovereignty (2005); C. Schmitt, The Nomos of the Earth in the International Law of the Jus Publicum Europaeum (2006).

${ }^{123}$ N. Berman, 'The Devil's Party: The Discourse of Demonisation in a Fracturing World', (2018) 6 London Review of International Law 127, at 132.

${ }^{124}$ G. Agamben, The Omnibus Homo Sacer (2017).

${ }^{125} \mathrm{~J}$. Whyte, Catastrophe and Redemption: The Political Thought of Giorgio Agamben (2013); G. Agamben, 'Capitalism as Religion', in D. McLoughlin (ed.), Agamben and Radical Politics (2016), 15.

${ }^{126} \mathrm{G}$. Agamben, Opus Dei: An Archaeology of Duty (2013).

${ }^{127}$ T. Asad, Formations of the Secular: Christianity, Islam, Modernity (2003).

${ }^{128}$ M. Foucault, Discipline and Punish: The Birth of the Prison (1977).

${ }^{129} \mathrm{On}$ the importance of Foucault and Nietzsche for his work, see ibid., 16.

${ }^{130}$ Ibid., 25.

${ }^{131}$ Ibid., 23 (emphasis in original). 
One could add, of course, male and female, public and private, civilized and barbaric. Postcolonial and feminist scholars like Mahmood and Scott, to cite two leading figures, have furthered this line of critique to reveal other dichotomies of the secular. ${ }^{132}$ In her work, Mahmood identifies secularism as a particular feature of modern political strategies of governance, which includes 'religious liberty, the legal distinction between public and private, the concept of public order, and the demographic category of religions minorities'. ${ }^{133}$ She is particularly concerned about the way in which these projects of modern secular governance have promoted imperial goals and, in practice, hardened 'interfaith boundaries and polariz[ed] religious difference'. ${ }^{134}$ Thus, even if secularism aims to create a post-religious public sphere (by reducing faith to the sphere of the private), it might end up intensifying 'pre-existing interfaith inequalities'. ${ }^{135}$ As her case studies show, secularism often ends up prompting a particularly Christian (and more precisely, Protestant) understanding of the role of the state, which creates violence and exclusion when it is imposed in colonial (and supposedly postcolonial settings). ${ }^{136}$ In her own words, one must interrogate the:

fundamental centrality of Christian norms, values, and sensibilities (however Judaic they are made out to be) to European conceptions of what it means to be secular. Prejudice against European Muslims today (and European and non-European Jews of the past) is constitutive of, and emanates from, this self-understanding of Europe as essentially Christian and simultaneously secular in its cultural and political ethos. ${ }^{137}$

Scott, in turn, would articulate a powerful historical critique of the gendered nature of secularism. In her comparative history of France and the United States, she shows that the association of womanhood with religion (as to entrench the connection between maleness and reason) was a 'hallmark of secularism discourse'. ${ }^{138}$ In her view, ' $[\mathrm{g}]$ ender difference was inscribed in a schematic description of the world as divided into separate spheres, public and private, male and female'. ${ }^{139}$ While this critique of the distinction between the public and private sphere has been mobilized by vibrant work in feminist approaches to international law, ${ }^{140}$ the connection between this dichotomy and the secular seems to be uncharted territory still for international lawyers.

In sum, post secularist literature has shown how this concept, rather than superseding religion, has in fact channeled, empowered, and regulated it. Secularism emerged a technique of governing religious life instead of negating it, and, as such, is imbricated with many theological concerns. Scott aptly shows how secularism did not shun belief, but rather attempted to 'tame' it, making it 'an aspect of the national patrimony and an instrument of colonial rule'. ${ }^{141}$ In fact, secularism grew as a strategy of Protestant political governance which 'presented itself as an aspect of the Christian tradition, [defining itself] as the liberal alternative (the right of individual conscience) not only to Catholicism but to the oppressive religions of the orient'. ${ }^{142}$

Bearing all of this in mind, thinking with Asad, Mahmood, and Scott allows us to challenge international law's triumphalist narrative of secularization. In fact, it shows us that the celebrated extrication of religion could be better seen as a Protestant critique of a Catholicism, that discarded

\footnotetext{
${ }^{132}$ S. Mahmood, Religious Difference in a Secular Age: A Minority Report (2015); J. Scott, Sex and Secularism (2017).

${ }^{133}$ Mahmood, supra note 132, at 208.

${ }^{134}$ Ibid., at 1 .

${ }^{135}$ Ibid., at 2 .

${ }^{136}$ Following, of course, E. W. Said, Orientalism (1979).

${ }^{137}$ Ibid., at 8 .

${ }^{138}$ See Scott, supra note 132 , at 30.

${ }^{139}$ Ibid., at 31 .

${ }^{140} \mathrm{H}$. Charlesworth and C. Chinkin, The Boundaries of International Law: A Feminist Analysis (2000), 56-9.

${ }^{141}$ See Scott, supra note 132, at 33.

${ }^{142} \mathrm{Ibid}$., at 33-4 (italics represented as quotation marks in the original).
} 
a particular understanding (papist, one could say) of religion to consecrate a model of Christian authority that was favourable to the rise of the territorial nation-state. ${ }^{143}$ At that time, the practices and discourses surrounding that model to be the field of knowledge came to be called raison d'Etat, which led to the birth of the modern state apparatus, with the development of its military-diplomatic assemblage (abroad), and the police authorities (within its own borders). ${ }^{144}$ Grotius, Vattel, Gentili, and Pufendorf were all protagonists of this historical process, and their alleged secularizing efforts are best seen as a Protestant critique of the previous Catholic eternal law (represented by Vitoria and Suarez ${ }^{145}$ ) in their personal and political efforts to serve the rising Protestant polities they served (the United Provinces, Saxony, England, Brandenburg, and Sweden, respectively). ${ }^{146}$ And just as the critique of secularism shows in domestic law, dichotomies also played a crucial role in international law's 'protestantization'. The public and private, Christian and pagan/heretic, the national and the international, the divine and the natural, comity and obligation, the spiritual and the temporal were mobilized to defend the nascent territorial jurisdiction of the state in its double struggle against the Pope and Emperor. ${ }^{147}$ One should read this process alongside Funkenstein's Theology and the Scientific Imagination. ${ }^{148}$ While we tend to think of the Classical Age as the time of the rise of man and the fall of religion, Funkenstein showed the heavy inheritance of 'modern' science to what he accurately called 'secular theology. ${ }^{149}$

With the emergence of the 'modern' discipline of international law in the nineteenth century, the dichotomy of Christian brother-heathen eventually subsided into the more familiar distinction between civilized and barbaric. ${ }^{150}$ Moved by a 'secular' spirit d'internationalité, the international lawyers of the late nineteenth century revived many of the dichotomies of the raison d'État age to push the backward peoples of the colonies into humanity's march towards (a non-religious) progress, by force if necessary. ${ }^{151}$ Suddenly, colonial governors at the core decried the lethargic and superstitious (even if recently invented) traditions of colonized peoples, blaming them for their lack of Christian love, civilized taste, or - later - economic development. ${ }^{152}$ While international law (or domestic western law, for that matter) prides itself on its secular forward-looking outlook, it continues to carry the weight of the heavy theological dichotomies that underpin the secular imagination. ${ }^{153}$ As Mahmood showed, western legal thought hinges on the contradiction of having the cake of religion but eating secularism too.

\footnotetext{
${ }^{143}$ M. Koskenniemi, 'International Law and Raison d'état: Rethinking the Prehistory of International Law', in B. Kingsbury and B. Straumann (eds.), The Roman Foundations of the Law of Nations: Alberico Gentili and the Justice of Empire (2010), 297.

${ }^{144}$ Foucault, supra note 1 , at 297.

${ }^{145}$ E. Dussel, 'Origen de La Filosofía Política Moderna: Las Casas, Victoria y Suárez (1514-1617)', (2005) 33(2) Caribbean Studies 35 .

${ }^{146} \mathrm{R}$. Tuck, The Rights of War and Peace: Political Thought and the International Order from Grotius to Kant (2001).

${ }^{147}$ I. Hunter, "The Figure of Man and the Territorialisation of Justice in "Enlightenment" Natural Law: Pufendorf and Vattel', (2013) 23 Intellectual History Review 289.

${ }^{148}$ A. Funkenstein, Theology and the Scientific Imagination: From the Middle Ages to the Seventeenth Century (2019).

${ }^{149}$ Ibid., at $360-4$.

${ }^{150}$ L. Obregón, 'The Civilized and the Uncivilized', in Fassbender and Peters, supra note 84, at 917.

${ }^{151}$ See Koskenniemi, supra note 109 , at 13; Anghie, supra note 86.

${ }^{152} \mathrm{~T}$. Ranger, 'The Invention of Tradition in Colonial Africa', in E. Hobsbawm (ed.), The Invention of Tradition (2012), 211; see Scott, supra note 132, at 122-55; A. Escobar, Encountering Development: The Making and Unmaking of the Third World (1995).

${ }^{153}$ D. Kennedy, 'International Law and the Nineteenth Century: History of an Illusion', (1996) 65 Nordic Journal of International Law 385; S. Hall, 'The Persistent Specter: Natural Law, International Order and the Limits of Legal Positivism', (2001) 12 EJIL 269; M. Koskenniemi, 'The Legacy of the Nineteenth Century', in D. Armstrong (ed.), Routledge Handbook of International Law (2009), 141.
} 
One could think of many examples of this in contemporary (international) legal thought. Scott picked the controversial Dahlab v. Switzerland case, in which a Swiss school dismissed a primary school teacher due to her conversion to Islam (and her use of the headscarf). ${ }^{154}$ She cited the ruling of a Swiss federal Court, which dismissed the case in 2001 because it was difficult to reconcile the principle of gender equality - which is a fundamental value of [Swiss] society'. ${ }^{155}$ Scott highlights the irony of this statement, especially considering that Switzerland only allowed access for all woman to the vote in 1971, showing the precariousness of a 'secular' commitment to gender equality. ${ }^{156}$ When this case came before the ECtHR, the tribunal upheld her removal as the measure pursued the 'legitimate aim of ensuring the neutrality of the [s]tate primary-education system'. ${ }^{157}$ Mahmood holds this past case in contrast with the Lautsi v. Italy decision, ${ }^{158}$ in which the ECtHR upheld the legality of crucifixes in Italian public schools. ${ }^{159}$ In this article, I do not want to add, yet another, opinion on whether the Court erred in its doctrinal analysis. ${ }^{160}$ Rather, following Moyn, I hold this case to be example of how religious freedom (under the cover of neutrality) is mobilized to protect Christian visions and to shun other religions like Islam. ${ }^{161}$ In fact, Moyn shows that the Lautsi outcome is no accident, as it responds clearly to the history of the ECHR, drafted as a bulwark of Conservative Christianity against the dangerous ghost of communist atheism. ${ }^{162}$ In conclusion, we can see that there is a growing body of literature that has, for the last two decades, provided the foundations for the critique of secularism. These diverse contributions show that 'the secular' often hides:

a form of ethnocentrism or crypto-Christianity, the particular product of the history of the European nation-state [which claims universalism and] has justified the exclusion or marginalization of those from non-European cultures (often immigrants from former colonies) whose systems of belief do not separate public and private in the same way, do not, in other words, conform to those of the dominant group. ${ }^{163}$

In what follows, I bring these insights into conversation with international law, to argue that one ought to understand Christianity as a technique of jurisdictional governance. Moreover, this particular technology of governmentality came to become a fundamental matrix for posterior Western legal (and political thought) and continues to underpin our understanding of normative authority. While we now tend to think that these institutions and doctrines are fully secularized, close historical scrutiny shows that:

all political and legal concepts are elastic, none ever proves to be exactly as malleable as any other. All bear the marks of their special historical trajectories, so long as partisans of some continuity in their meaning remain to fight on its behalf. ${ }^{164}$

\footnotetext{
${ }^{154}$ See Scott, supra note 132 , at 17.

${ }^{155}$ Ibid.

${ }^{156}$ Ibid.

${ }^{157}$ Dahlab v. Switzerland, Decision of 15 February 2001, [2001] ECHR V.

${ }^{158}$ Lautsi and others $v$. Italy, Judgment of 18 March 2011, [2011] ECHR.

${ }^{159}$ See Mahmood, supra note 132 , at 7.

${ }^{160}$ For that debate see D. Kyritsis and S. Tsakyrakis, 'Neutrality in the Classroom', (2013) 11 International Journal of Constitutional Law 200; contrast with J. Weiler, 'Lautsi: A Reply', (2013) 11 International Journal of Constitutional Law 230.

${ }^{161}$ S. Moyn, 'Religious Freedom and the Fate of Secularism', in J. Cohen and C. Laborde (eds.), Religion, Secularism, and Constitutional Democracy (2016), 27.

${ }^{162} \mathrm{Ibid}$., at 30 . See also Duranti, supra note 47. Recent literature, it must be noted, has also explored the tense relationship between atheism and Communism. See V. Smolkin, A Sacred Space Is Never Empty: A History of Soviet Atheism (2018).

${ }^{163} \mathrm{~J}$. Scott, The Politics of the Veil (2010), 92.

${ }^{164}$ See Moyn, supra note 118 , at 28.
} 


\section{Christianity as jurisdiction}

\subsection{Jurisdiction as technology}

Dorsett and McVeigh offer us a rich theory of what a 'jurisprudence of jurisdiction' might look like. ${ }^{165}$ They start their argument by recognizing that, in the western tradition, the concern of jurisdiction ('the power to speak the law, and to decide what law is') was the first legal question that can be raised. ${ }^{166}$ Only after the preliminary matter of jurisdiction has been established, can questions of lawful conduct, justice, and equality emerge. It is thus a jurisprudence that inaugurates the exercise of normative authority. As they note, there is:

an insistent materiality to questions of jurisdiction that can be approached in terms of institutional practice or pragmatics. At the centre of these practices are the various devices, techniques[,] and technologies that make the enunciation and life of the law possible. ${ }^{167}$

In particular, they analyse four ways in which technologies of jurisdiction are central to the western institutional repertoire: writing, mapping, precedent, and categorization. ${ }^{168}$ Thus, instead of assuming a 'natural link between sovereignty, territory and land', they argue one should interrogate the way these four technologies 'authorize' and 'ground' visions of normative world-making. Here, we all draw from Cover, who put forward a theory of jurisdiction that linked 'a justice "yetto-come" to an institutional account of the practical reasoning of the judge that restages a rolebound jurisdiction of violence.' ${ }^{169}$ I bring these insights in conversation with the history of Christianity to see how this religion mobilized jurisdictional technologies to create authoritative accounts of lawful conduct. In particular, I will interrogate the 'roles' created to bound jurisdiction, arguing that Christianity was built around the institution of the pastor. Eventually, these techniques of power came to be adopted by the state and contemporary structures of global governance, albeit in a supposedly secularized fashion. Against this, I suggest that the pastor continues to act as an office around which jurisdiction pivots, setting a mould for the disciplinary practice of international lawyers. Crucially, the pastoral comes forward especially when international lawyers attempt to engage with 'extra-territorial' jurisdiction. The critique of secularism reveals the continuity of pastoral ambitions in our contemporary discussion on jurisdiction beyond territory.

My focus on the intimate link between jurisdiction and Christianity, however, does not seek to claim that Western religions were the only ones that articulated visions of authority that pretended to speak for the law. Indeed, as Becker-Lorca and others have shown, semi-peripheral jurists and states often invoked their own grounds of jurisdictional power to contest western imperial designs. ${ }^{170}$ Recently, Saksena and Singh have shown how the so-called princely states of India actively used jurisdictional language to challenge British colonial imposition, challenging traditional assumptions about the one-way 'export' of legal technologies from the core to the periphery. ${ }^{171}$ Along these lines, Khan, Pahuja, and McVeigh - among others - are currently attempting to pluralize our histories and theories of jurisdiction, highlighting the importance that colonized peoples from the Global South gave to different understandings of the intermingled

\footnotetext{
${ }^{165}$ S. McVeigh and S. Dorsett, 'Questions of Jurisdiction', in S. McVeigh, Jurisprudence of Jurisdiction (2013), 3.

${ }^{166}$ S. McVeigh, 'Critical Approaches to Jurisdiction and International Law', in Allen et al., supra note 55, at 183.

${ }^{167}$ See McVeigh and Dorsett, supra note 165 , at 4.

${ }^{168}$ See Dorsett and McVeigh, supra note 23, at 54-80.

${ }^{169}$ See McVeigh and Dorsett, supra note 165, at 8. On Cover, see supra notes 26, 27.

${ }^{170}$ A. Lorca, supra note 91 , at $76 \mathrm{ff}$.

${ }^{171}$ P. Saksena, 'Jousting Over Jurisdiction: Sovereignty and International Law in Late Nineteenth-Century South Asia', (2020) 38 Law and History Review 409; P. Singh, 'Indian Princely States and the 19th-Century Transformation of the Law of Nations', (2020) 11 Journal of International Dispute Settlement 365.
} 
offices of the priest, the jurist, and the diplomat. ${ }^{172}$ My focus on western Christianity, then, hinges on an attempt to provincialize it - to show how this seemingly universal language actually responds to particular contexts, events, and accidents in the history of the continent we call Europe. $^{173}$

\subsection{The Lord is my shepard: Pastoral power and the history of governmentality}

In his genealogy of governmentality, Foucault was particularly interested in the practices and discourses related to the 'pastoral type or power' that would eventually lead to the development of the diplomatic-military/police complex that we now call the state. ${ }^{174}$ Foucault notes that this particular model was not endemic to the 'western tradition' of Greek and Roman thought, but was rather incorporated into this canon in the syncretic adoption of traditions of political theory from the Mediterranean East into the Roman Empire 'by the way of the Christian Church'. ${ }^{175}$ In fact, by reconstructing the scattered mentions of the relationship between the magistrate and the pastor in Plato's work, Foucault concludes that for the Greco-Roman political imagination, authority was constructed especially in territorial terms, around the limits of the city-state. ${ }^{176}$ Plato saw that the appropriate model for the office of the magistrate was that of the weaver, who expertly conducts the art of politics for the organized polis, rather than the pastor and his moving flock. ${ }^{177}$

On the other hand, the peoples of the Eastern Mediterranean (and particularly the Hebrew faith) saw themselves as a people in movement, whose institutions of authority were not particularly tied down to a fixed territory. Therefore, Judaic theology began with the plight of exodus and entrusted the pastor with the difficult institutional role of leading the flock through the dangerous country. ${ }^{178}$ This jurisdictional expansion, however, was not boundless. The pastor only spoke the law that was derived from the sacred covenant between God and the Jewish people. Roman jus civile, one must add, was quite similar to the Judaic formula. Although it had no territorial limits, it depended on the ties of personal allegiance: we now call this citizenship. ${ }^{179}$ Christianity's theological innovation lied in that it claimed jurisdictional authority not over a delimitated territory (like the Greek polis) or a determinate people (like the Jewish flock) but over all of humankind. In Foucault's words, the pastorate as a 'matrix of procedures for the government of men' only began with:

a process that is absolutely unique in history and no other example of which is found in the history of any other [sic] civilization: the process by which a religion, a religious community, constitutes itself as a Church, that is to say, as an institution that claims to govern men in their daily life on the grounds of leading them to eternal life in the other world, and to do this not only on the scale of a definite group, of a city or a state, but of the whole of humanity. ${ }^{180}$

As it is well known, Foucault was interested in the ways in which these pastoral techniques were later adopted by classical, modern, and contemporary procedures of truth-making and

\footnotetext{
${ }^{172}$ For instance, in August 2019 these scholars convened an event at Melbourne Law School's Institute for International Law and the Humanities on the topic of the 'Offices of the Southern Jurist Diplomat: Taking up a Training in Conducting Lawful Encounters', available at law.unimelb.edu.au/centres/iilah/research/offices-of-the-southern-jurist-diplomat.

${ }^{173}$ See further D. Chakrabarty, Provincializing Europe: Postcolonial Thought and Historical Difference (2008). See also M. Koskenniemi, 'Histories of International Law: Dealing with Eurocentrism', (2011) 19 Rechtsgeschicte 152.

${ }^{174}$ Foucault, supra note 1 , at 123 . As an introduction see Golder, supra note 20.

${ }^{175}$ Foucault, ibid., at 129 .

${ }^{176}$ Ibid., at $136-47$.

${ }^{177}$ Ibid., at 146 .

${ }^{178}$ On Rabbinic commentary of Moses and the Flock of Israel, ibid., at 127.

${ }^{179}$ See Tuori, supra note 92 , at 32.

${ }^{180}$ Ibid., at 148 .
} 


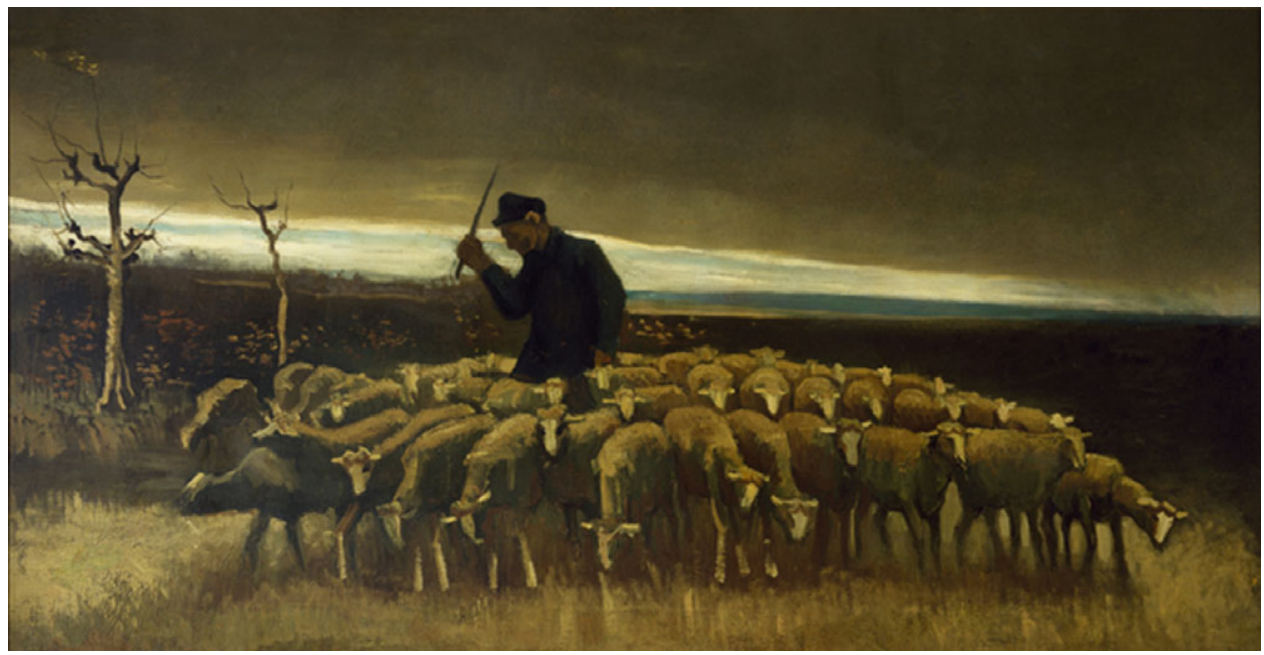

Figure 1: Vincent Van Gogh. After the Storm (or Shepherd with a Flock of Sheep), 1884, oil on canvas, $66.3 \times 128.5 \mathrm{~cm}$, Mexico City, Museo Soumaya - Fundación Carlos Slim.

subjectivation (see, for instance, the importance of the confession for both legal and sexual fidelity). ${ }^{181}$ In fact, the recurring concerns that underpin his work were the innumerable intersections between jurisdiction and veridiction that [are] undoubtedly a fundamental phenomenon of the modern West'. ${ }^{182}$ Thus, I would like to approach the history of Christianity as an assembly of practices and discourses that attempted to use the institution of the pastor to link a set of jurisdictional claims and religious beliefs. The pastor, in other words, was given the jurisdictional task of being the Vicar of Christ: tasked with the perilous office of guiding his (endless) flock in the pursuit of divine truth. ${ }^{183}$ From then, our legal magistrates have been entrusted mutatis mutandis to embrace the figure of the pastor, and our kings, judges, and leaders have been created in His own image. If Foucault famously claimed that political theory has not cut off the head of the king yet, ${ }^{184}$ I argue that jurisprudence and legal theory still rest on the shepherd's crook.

Instead of offering a comprehensive history of the Catholic church, ${ }^{185}$ in what follows I will highlight the importance of the pastoral office of the Pope for the articulation of mechanisms of jurisdiction and veridiction in Christian governmentality. I argue that one must understand the birth of territorial nation-states (and therefore, of the question of 'extraterritorial jurisdiction') in the backdrop of the theological disputes over the scale and scope of pastoral power. But before, let us stand before Van Gogh's representation of pastoral authority (Figure 1). As Manderson reminds us, '[i]mages are prime sites of law's theory and law's praxis. They are also, on occasion, prime sites for the critique of law, too' ${ }^{186}$

\subsection{Jurisdictions before the state: Orderly disorders before the birth of territory}

As Weber noted in this comparative sociology of 'world' religions, one distinctive aspect of Christianity was its hierarchical organization around the institution of the bishop. ${ }^{187}$ This officer

\footnotetext{
${ }^{181}$ M. Foucault, Histoire de La Sexualite IV: Les Aveux de La Chair (2018).

${ }^{182} \mathrm{M}$. Foucault, The Birth of Biopolitics: Lectures at the Collège de France (2008), 34.

${ }^{183}$ J. Reid, 'Vicar of Christ', (1982) 35 Scottish Journal of Theology 133. The use of the male pronoun here is deliberate.

${ }^{184}$ M. Foucault, The History of Sexuality. Volume I: An Introduction (1978), 88-9.

${ }^{185}$ See, as an introduction, J. McManners (ed.), The Oxford History of Christianity (2002).

${ }^{186}$ D. Manderson, Danse Macabre: Temporalities of Law in the Visual Arts (2019), 16.

${ }^{187}$ M. Weber, The Sociology of Religion (1965), 74.
} 
was entrusted with presiding in the absence of God, and (according to theology) was initially entrusted to Peter Simon when Christ told him to 'feed his sheep'. ${ }^{188}$ As historians of theological thought have shown, the mantle of 'the bishop' was entrusted to leaders of Christian congregations since at least the third century. However, from the establishment of Christianity up to the fifth century there had been no such thing as a pope. In fact, spiritual authority was divided amongst the bishops of the different sedes apostolicae (churches that had been founded by an apostle): Antioch, Philippi, Ephesus, Corinth, Thessalonica, and Rome. ${ }^{189}$ While Rome could claim the dual presence of the apostles, Paul and Peter, there were no 'clear-cut claims, or recognition of, papal primacy. ${ }^{190}$ The movement of the imperial capital to Constantinople added another warring faction to the many dioceses of the East, while Rome was left undisturbed as the sole high see of the West. With the power vacuum generated by the fall of the Western Roman Empire, the Bishops of Rome claimed their mantle as vicar of Christ, primus inter pares. For Agamben, entrusting him with the responsibility for the whole church enabled the reconciliation of the 'spiritual dignity (the possession of charismas) with the carrying out of a juridical-bureaucratic function' permitting 'the celebration of the divine mysterium as the fulfillment of a human ministerium' ${ }^{191}$ Ever since, the Pope was tasked with keeping the keys to the dialectic of jurisdiction/veridiction, acting not only as a dogmatic authority but also as a temporal institution of government. In this context, the church defined:

[t]he area of jurisdiction [as] a functionally delimited realm of possible objects for commands and thus the sphere of the official's legitimate power ... The pastor or priest has his definitely limited "jurisdiction", which is fixed by rules. This also holds for the supreme head of the church. The present concept of papal "infallibility" is a jurisdictional concept. ${ }^{192}$

And this, in turn, brought the birth of 'the global pastor' in the office of the Pope. This new power, both spiritual and temporal, created a powerful innovation in the techniques of the governance of men and women. While Greek power was bounded by territory (the polis) and Roman jus civile/ Jewish divine law was limited to a determined people (citizens/the chosen people), the Pope claimed to speak to and on behalf of all humanity. He, and only he, was not only Christ's vicar, but the bishop of all humankind. This 'presumption of universalism' set the stage for the almost two millennia of struggles for, against, and in pastoral politics. For instance, while the eastern dioceses recognized the importance of Rome, they refused to accept its claim to supreme temporal and spiritual power, leading to the East-West schism of $1054 .{ }^{193}$ Two decades later, the Pope would also quarrel with the resurgent Holy Roman Emperor, leading to the famous investiture controversy. ${ }^{194}$ As Bartelson notes:

Papal superiority in ... legal disputes ... was facilitated by a gradual accumulation of archives and registers. The church had a past of its own, consisting of a continuity of texts linked together by continuity of commentary and interpretation ... what was outside this

\footnotetext{
${ }^{188}$ John 21:15-17 (King James Bible). To be sure, I am citing this document as a literary piece of historical relevance, and not as any invocation of authority, divine or otherwise. J. Gabel (ed.), The Bible as Literature: An Introduction (2006).

${ }^{189}$ K. Schatz, Papal Primacy: From Its Origins to the Present (1996), 7.

${ }^{190}$ D. W. Kling, The Bible in History: How the Texts Have Shaped the Times (2004), 61.

${ }^{191}$ Agamben, supra note 126, at 81-2.

${ }^{192}$ M. Weber, 'The Social Psychology of the World Religions', in H. Gerth and C. Mills, From Max Weber: Essays in Sociology (1998), 267, at 295.

${ }^{193}$ A. E. Siecienski, The Papacy and the Orthodox: Sources and History of a Debate (2017), 240-81.

${ }^{194}$ Hicks, 'The Investiture Controversy of the Middle Ages, 1075-1122: Agreement and Disagreement among Historians', (1973) 15 Journal of Church and State 5.
} 
body of texts, ranging as it did from the very words of God down the tiniest legal protocol, was not admitted as knowledge. ${ }^{195}$

Unsurprisingly, we see that many of the technologies associated with contemporary legal orders and their jurisdictional operations have long roots in papal (and anti-papal) modes of controversy.

But power, as Foucault was well aware, was not stable and perennial. ${ }^{196}$ Every conduct imposed by technology of governmentality tends to lay the groundwork for later counter-conducts that undermines the original mechanism of discipline. ${ }^{197}$ Hence, further disputes with the powers (both temporal and spiritual) would lead to the emergence of a plethora of antipopes -and even another great schism within the Latin church throughout the late middle ages. ${ }^{198}$ By the early fourteenth century, the church had developed a 'theory of near-absolute papal monarchy'. ${ }^{199}$ As we know well, further disagreements led to the Reformation and Counter-Reformation movements of the sixteenth century ${ }^{200}$ in a period 'in which modern states begin to take shape while Christian structures tighten their grip on individual existence'. ${ }^{201}$ Vitoria's rejection of papal authority over the Americas (and his move towards a more 'secular' natural law) but one of the many instances of pastoral disputes over international authority. ${ }^{202}$

In sum, with Foucault, we can conclude that:

the importance, vigor, and depth of the implantation of this pastoral power can be measured by the intensity and multiplicity of agitations, revolts, discontents, struggles, battles, and bloody wars that have been conducted around, for, and against it. The immense dispute over the gnosis that divided Christianity for centuries is to a large extent a dispute over the mode of exercising pastoral power. ${ }^{203}$

The pastoral created a template for jurisdictional authority before the existence of the state. In fact, one could retell the history of Western political thought not as a narrative of secularization that eventually led to the rise of the state, but rather as a divisive contest between petty kings, roving and stationary bandits, the Holy Roman Empire, and the Pope for the mantle of the Vicar of Christ. ${ }^{204}$ In fact, we can reread the leading works of sociologists like Sassen, historians like Kantorowicz, Benton, Herzog or Wood, political theorists like Tilly, or critical geographers like Elden to see the many ways in which the 'great battle of pastorship [that] traversed the West from

\footnotetext{
${ }^{195}$ J. Bartelson, A Genealogy of Sovereignty (1995), 93.

${ }^{196}$ M. Foucault, 'On Popular Justice: a Discussion with the Maoists', in C. Gordon (ed.), Power/Knowledge: Selected Interviews and Other Writings, $1972-1977$ (1980), 1; D. F. Bouchard (ed.), Language, Counter-Memory, Practice: Selected Essays and Interviews (1980). I thank one of the editors for his/her/their invitation to be more precise on this point.

${ }^{197}$ See, for instance, B. L. Pickett, 'Foucault and the Politics of Resistance', (1996) 28 Polity 445; C. Death, 'CounterConducts: A Foucauldian Analytics of Protest', (2010) 9 Social Movement Studies 235; B. Golder, Foucault and the Politics of Rights (2015), 31-60.

${ }^{198}$ H. Kaminsky, 'The Great Schism', in M. Jones (ed.), The New Cambridge Medieval History (2000), 674.

${ }^{199}$ C. Zuckerman, 'Aquinas' Conception of the Papal Primacy in Ecclesiastical Government', (1973) 40 Archives d'histoire Doctrinale et Littéraire Du Moyen Âge 97, at 97.

${ }^{200}$ C. Dixon, 'Luther's Ninety-Five Theses and the Origins of the Reformation Narrative', (2017) 132 The English Historical Review 533.

${ }^{201}$ M. Foucault, Abnormal: Lectures at the Collège de France 1974 - 1975 (2003), 177. See further J. Zunckel, 'Affirming Papal Supremacy_Shaping Catholicism: The Readjustment of Symbolic Resources at the Post-Trent Roman Court', in B. Boute and T. Småberg (eds.), Devising Order: Socio-religious Models, Rituals, and the Performativity of Practice (2012), 145.

${ }^{202}$ See Anghie, supra note 86, at 18; C. Phillipson, 'Franciscus a Victoria (1480-1546). International Law and War', (1915) 15 Journal of the Society of Comparative Legislation 175, at 182; P. Niemelä, 'A Cosmopolitan World Order? Perspectives on Francisco de Vitoria and the United Nations', (2008) 12 Max Planck Yearbook of United Nations Law 301, at 311; Amorosa, supra note 115 , at 136.

${ }^{203}$ Foucault, supra note $1,149$.

${ }^{204}$ Tuori, supra note 92, at 35; K. Rennie, The Foundations of Medieval Papal Legation (2013), 20.
} 
the thirteenth to the eighteenth century' unfolded. ${ }^{205}$ Perhaps, what we now call and revere as the 'nation-state' was nothing else than a tentative Protestant formulation of scale attempted to fix the limit of pastoral governmentality to a territorial space and a defined political community, always under the contestation of smaller local and wider global forms of pastoral imagination. Instead of a long teleological march from a religious past into a secular present, we have a messy picture of competing models of papal-like authority.

The struggle of 'secular' and protestant polities against Catholic ultramontanism in the nineteenth century should be read as one of many disputes in the Western pastoral about the territorial (or lack thereof) delimitations of papal primacy. In 1870, the Catholic Church nailed its thesis to the door when in the constitutio dogmatica Pastor aeternus it consecrated the jurisdiction and authority of the Pope over all peoples, in matter both spiritual and temporal. ${ }^{206}$ Interestingly enough, this occurred at the same time as the Italian nation-state claimed jurisdiction over the whole city of Rome. When it occupied the city later that year, Italy confined the territorial jurisdiction of the papacy to the Vatican enclosure. ${ }^{207}$ This, of course, did not bring an end to papal political influence. James Brown Scott celebrated that while the Lateran Treaty reduced the temporal power of the Pontiff, it also recognized larger spiritual sovereignty. ${ }^{208}$ For this reason, the Pope was an 'ideal arbitrator of international' disputes, holding the keys to the kingdom of justice and truth. ${ }^{209}$ While the mantle of vicar was eventually bestowed instead on the new international courts and tribunals of the twentieth century, shows how the model of the papacy continues to underly (international) law's claims to authority. Not in vain, Moynier imagined the Institut de Droit International as a 'juridico-ecumenical council, without pope or infallibility ${ }^{210}$ while Oppenheim felt it important to clarify that 'Grotius was not an infallible pope'. ${ }^{211}$ Another, more contemporary, example may be found in the recent statement issued by the bishops of Bolivia denying the recent coup against indigenous leader Evo Morales (who, in turn, asked for papal intervention in his favour ${ }^{212}$ ). This shows the continuing relevance of Christian institutions in the mediation between jurisdiction and veridiction. ${ }^{213}$ As Foucault noted, 'there have been anti-feudal revolutions; there has never been an anti-pastoral revolution. The pastorate has not yet experienced the process of profound revolution that would have definitively expel it from history' ${ }^{214}$

Indeed, this article offers but a brief vignette of the long history of the pastorate as a model for later forms of political and social organization. Foucault's later work would insist that pioneer Christian rituals (such as the confession) would be central to the articulation of modern forms of bureaucratic individualization. ${ }^{215}$ In this light, liberalism is an outgrowth rather than a

\footnotetext{
${ }^{205}$ See Foucault, supra note 1, at 149. See also Sassen, supra note 75; E. Kantorowicz, The King's Two Bodies (2016); Benton, supra note 74; Herzog, supra note 74; E. Wood, Citizens to Lords: A Social History of Western Political Thought from Antiquity to the Middle Ages (2011); Tilly, supra note 94; Elden, supra note 76 (2013, 2017).

${ }^{206}$ See w2.vatican.va/content/pius-ix/la/documents/constitutio-dogmatica-pastor-aeternus-18-iulii-1870.html.

${ }^{207}$ J. Corrin, 'The Black International, 1870-1878: The Holy See and Militant Catholicism in Europe (Review)', (2003) 89 The Catholic Historical Review 312.

${ }^{208} \mathrm{P}$. Amorosa, supra note 115 , at $215-16$.

${ }^{209}$ Ibid., at 217.

${ }^{210}$ In its original French, 'un espèce de concile juridique-oecuménique, sans pape et sans infallibilitê. Cited in Koskenniemi, supra note 109 , at 37.

${ }^{211}$ L. Oppenheim, 'The Science of International Law: Its Task and Method', (1908) 2 AJIL 313, at 328.

${ }^{212}$ E. Castillo, 'Evo Morales Wants the U.N.—and Maybe Pope Francis—to Mediate in Bolivia', America: the Jesuit Review, 15 November 2019, available at www.americamagazine.org/politics-society/2019/11/15/evo-morales-wants-un-and-maybepope-francis-mediate-bolivia.

${ }^{213}$ Rome Reports, 'Obispos de Bolivia: Lo Que Sucede No Es Un Golpe de Estado', available at www.romereports.com/2019/ 11/11/obispos-de-bolivia-lo-que-sucede-no-es-un-golpe-de-estado/.

${ }^{214}$ Foucault, supra note 1 , at 150.

${ }^{215}$ M. Foucault, Omnes et Singulatim: Towards a Criticism of 'Political Reason' (1979); P. Savoia, 'Foucault's Critique of Political Reason: Individualization and Totalization', (2012) 35 Revista de Estudios Sociales 14.
} 
supersession of previous religious ways of thinking. ${ }^{216}$ Biopolitical interventions, and even contemporary neoliberal forms of governmentality, can be productively read as sophisticated elaborations of the tried Christian repertoire. ${ }^{217} \mathrm{My}$ aim here is not to reproduce the important contributions of other fields of knowledge on the relation to 'modern' technologies of government and 'ancient' religious rites, but rather to bring these insights in our own field to challenge the confidence of international lawyers with the so-called secularization of the discipline. Jurisdiction is one of the many theological concepts that legal scholars and practitioners regularly use without reflecting on its heavy inheritances.

At the same time, I must clarify that this does not mean that I am necessarily putting forward a different, pluralized, or postcolonial account of jurisdictional thinking. There is an important debate within the 'critical' tradition regarding the possibilities of Reformation (no pun intended) in contemporary international law. ${ }^{218}$ To be sure, the emerging chorus of Marxist and critical voices leaves ample room for disagreement. ${ }^{219} \mathrm{I}$ understand why some readers might be disappointed with not finding in this article an extended discussion of the counter-conducts - past, present, and future - that can be used to challenge the Christian legacy of jurisdiction thinking to reform and secularize international legal discourse. ${ }^{220}$ While this is an important project, in this article I did not aim to provide recipes (legal or otherwise) for the cookbooks of the future. ${ }^{21}$ Instead, I intended to provincialize and problematize international law's presumption of territoriality. ${ }^{222}$ I argue that MILS' certainties about the normalcy of territorially-bound jurisdiction can only be sustained when one ignores the centrality of Christian extraterritoriality in western thought. To think about jurisdiction in this way requires a specific form of forgetting. ${ }^{223}$ Moreover, I argue that TWAILers (and other fellow travellers of the critical roads), have perhaps also forgotten the burning influences of religious practices in our critique of the cold monster that we call the state. ${ }^{224}$

But this article does not seek to provide the last word. In my view, it opens a set of questions related to how specific techniques of governing that are common in contemporary international law have been shaped by and large in the mould of religious rites. This may include, inter alia, the long road from the confession to the testimony; ${ }^{25}$ from the papal nuncio to the

\footnotetext{
${ }^{216}$ J. Simpson, Permanent Revolution: The Reformation and the Illiberal Roots of Liberalism (2019)

${ }^{217}$ Foucault, supra note 182. See also D. Leshem, The Origins of Neoliberalism: Modeling the Economy from Jesus to Foucault (2017)

${ }^{218}$ See, for instance, C. Miéville, ‘The Commodity-Form Theory of International Law: An Introduction', (2004) 17 LJIL 271; C. Miéville, Between Equal Rights: A Marxist Theory of International Law (2005); and compare with B. S. Chimni, 'Concluding Response from Professor Chimni: International Law and World Order, EJIL:Talk!, 29 December 2017, available at www. ejiltalk.org/concluding-response-from-professor-chimni-international-law-and-world-order/; or E. P. Thompson, Whigs and Hunters: The Origin of the Black Act (1975), 264. See further B. Rajagopal, International Law from Below: Development, Social Movements and Third World Resistance (2003); R. Knox, 'Marxism, International Law, and Political Strategy', (2009) 22 LJIL 413; supra note 69; G. M. Lentner, 'Beyond Cynicism and Critique: International Law and the Possibility of Change', in B. Baade et al. (eds.), Cynical International Law? Abuse and Circumvention in Public International and European Law (2020), 37.

${ }^{219} \mathrm{G}$. Baars, The Corporation, Law and Capitalism: A Radical Perspective on the Role of Law in the Global Political Economy (2019); N. Tzouvala, Capitalism as Civilisation: A History of International Law (2020); M. Pal, Jurisdictional Accumulation: An Early Modern History of Law, Empires and Capital (2020);

${ }^{220}$ See supra note 197. I thank one of the editors for raising this point.

${ }^{221}$ To paraphrase J. K. Marx, Le Capital: Critique de l'Économie Politique (1983), 15. In the original French, 'de m'être borné à un simple démontage critique du donné, au lieu de forumler des recettes (comtistes?) pour les gargotes de l'avenir'.

${ }^{222}$ See supra note 173.

${ }^{223}$ M. Jordin, 'Film and Popular Memory: Interview with Michel Foucault', (1975) 11 Radical Philosophy 25; G. M. Lentner, 'Law, Language, and Power: English and the Production of Ignorance in International Law', (2020) 8 International Journal of Language and Law 50.

${ }^{224}$ See supra note 17.

${ }^{225}$ G. P. Martin and J. Waring, 'Realising Governmentality: Pastoral Power, Governmental Discourse and the (Re) Constitution of Subjectivities', (2018) 66 The Sociological Review 1292.
} 
ambassador; ${ }^{226}$ from protestant dissent to freedom of religion; ${ }^{227}$ from the exegesis of the bible to the interpretation of international judgments as 'holy writs'; ${ }^{228}$ or from to the figure of the Christian missionary to the humanitarian delegate that ventures bravely into the field. ${ }^{229}$

\section{Concluding remarks: Training the shepherds of humanity}

Much ink has been spilled on the birth of international law as a profession, ${ }^{230}$ especially after Koskenniemi and Kennedy invited us to think of 'international law as what international lawyers do and how they think ${ }^{231}$ (and, most importantly, of the particular political projects they mobilize when they act and think ${ }^{232}$ ). Usually, this process of disciplinary formation is told as a twin narrative of 'autonomization' (with the emancipation of international law from religion or politics) and 'scientification' (with the rise of legal positivism). ${ }^{233}$ When we draw from critiques of secularism reviewed above, it seems clear that this is not much more than an exercise of wishful thinking (at its best), and a misleading myth (at its worst). In fact, international law continues to inhabit the pastoral mould, and one cannot understand its triumphs, shortcomings, and biases without delving into the universal aspirations of the Vicar of Christ.

Elsewhere, I have explored the 'cosmopolitan dream' that has animated international law since its inception. ${ }^{234}$ In that piece, I argued that the 1990s led to a resurgence of cosmopolitan legal consciousness, in which dreams of human rights, free trade, and the international rule of law that had been shackled since 1945, 1873, or even 1648 suddenly found themselves unshackled from their Cold War prison. The spirit d'internationalité the Koskenniemi traced in the late nineteenth century is still living well today. As he himself noted, for many ' $[t]$ aking international law as one's professional career simultaneously seems to opt for a politics that favours global governance over national sovereignty, human rights over domestic jurisdiction, integration over independence', often combining 'Grotian humanism, Kantian cosmopolitanism[,] and Wilson's institutional faith'. ${ }^{235}$ Koskenniemi then puts forward four distinct Weberian models of professional commitment: the judge ${ }^{236}$ the adviser, ${ }^{237}$ the activist, ${ }^{238}$ and the academic. ${ }^{239}$

Underlying all those models, I suggest, lies the pastor. Underneath the façade of liberal and secular commitments, these ideal types are different contemporary formulas to address the old question of the vicariate. They embody diverse responses to the perennial jurisdictional inquiry: who speaks for the law? They push for diverging technologies of authority; scales of jurisdictional

\footnotetext{
${ }^{226}$ A. Preston, 'The religious turn in diplomatic history', in F. Costigliola and M. Hogan (eds.,) Explaining the History of American Foreign Relations (2016), 284.

${ }^{227}$ U. Greenberg, 'Is Religious Freedom Protestant? On the History of a Critical Idea', (2020) 88 Journal of the American Academy of Religion 74.

${ }^{228}$ See Bianchi, supra note 14, at 248, citing R. Jennings, 'The Role of the International Court of Justice', (1997) 68(1) British Year Book of International Law 1, at 41.

${ }^{229}$ D. Rodogno, 'Certainty, Compassion and the Ingrained Arrogance of Humanitarians', in N. Wylie et al. (eds.), The Red Cross movement: myths, practices and turning points (2020), 27, at 35.

${ }^{230}$ A. Orford, 'Scientific Reason and the Discipline of International Law', in d'Aspremont et al., supra note 29 , at 93.

${ }^{231} \mathrm{M}$. Koskenniemi, 'Between Commitment and Cynicism: Outline for a Theory of International Law as Practice', in d'Aspremont et al., ibid., 38, at 65.

${ }^{232}$ See Kennedy, supra note 67, at 466.

${ }^{233}$ J. d'Aspremont, 'The Professionalisation of International Law', in d'Aspremont et al., supra note 29, at 19.

${ }^{234}$ See Quiroga-Villamarín, supra note 6. Here I follow D. Kennedy, 'One, Two, Three, Many Legal Orders: Legal Pluralism and the Cosmopolitan Dream', (2006) 31 NYU Review of Law and Social Change 641; Orford, supra note 10, at 186-219; D. Kennedy, 'Three Globalizations of Law and Legal Thought: 1850 - 2000', in D. Trubek and A. Santos (eds.), The New Law and Economic Development: A Critical Appraisal (2006), 19.

${ }^{235}$ See Koskenniemi, supra note 231 , at $38-9$.

${ }^{236} \mathrm{Ibid}$., at 54-68.

${ }^{237}$ Ibid., at $58-60$.

${ }^{238}$ Ibid., at 61-3.

${ }^{239}$ Ibid., at 63-5.
} 
intervention; and patterns of lawful conduct. But, when all is said and done, none of them fundamentally departs from the theological concern over how to navigate the turbulent waters between jurisdiction and truth in the never-ending quest of governing humankind. Dismissing the 'primitive parochialism' of his fellow domestic lawyer, ${ }^{240}$ the international lawyer claims a higher diocese than the petty nation-state. She aspires to become the true Bishop of Rome, holding the keys for the kingdom of the Universal. For Humanity's vicar, there is nothing beyond her grasp.

\footnotetext{
${ }^{240}$ D. Kennedy, 'The Twentieth-Century Discipline of International Law in the United States', in A. Sarat, B. Garth and R. Kagan (eds.), Looking Back at Law's Century (2002), 386.
}

Cite this article: Quiroga-Villamarín DR (2021). Vicarius Christi: Extraterritoriality, pastoral power, and the critique of secular international law. Leiden Journal of International Law 34, 629-652. https://doi.org/10.1017/S0922156521000285 